\title{
The heat-capacity of ilmenite and phase equilibria in the system Fe-Ti-O*
}

\author{
Lawrence M. anovitz $Z^{1}$, Allan H. Treiman ${ }^{2}$, Eric J. Essene', Bruce S. Hemingway ${ }^{3}$, \\ EDGAR F. Westrum JR. ${ }^{4}$, Victor J. Wall ${ }^{5}$, RAMÓN BURRIEL ${ }^{6}$ and STEVEn R. BOHLEN?
}

(Received September 20, 1984; accepted in revised form June 21, 1985)

\begin{abstract}
Low temperature adiabatic calorimetry and high temperature differential scanning calorimetry have been used to measure the heat-capacity of ilmenite $(\mathrm{FeTiO})$ from 5 to $1000 \mathrm{~K}$. These measurements yield $S_{298}^{0}=108.9 \mathrm{~J} /(\mathrm{mol} \cdot \mathrm{K})$. Calculations from published experimental data on the reduction of ilmenite yield $\Delta G_{298}^{0}(\mathrm{II})=-1153.9 \mathrm{~kJ} /(\mathrm{mol} \cdot \mathrm{K})$. These new data, combined with available experimental and thermodynamic data for other phases, have been used to calculate phase equilibria in the system Fe-Ti-O. Calculations for the subsystem Ti-O show that extremely low values of $\mathrm{fO}_{2}$ are necessary to stabilize TiO, the mineral hongquiite reported from the Tan district in China. This mineral may not he TiO, and it should be re-examined for substitution of other elements such as $\mathbf{N}$ or $\mathbf{C}$. Consideration of solid-solution models for phases in the system Fe-Ti-O allows derivation of a new thermometer/oxybarometer for assemblages of ferropseudobrookite-pseudobrookite, and hematite-ilmenite. Preliminary application of this new thermometer/oxybarometer to lunar and terrestrial lavas gives reasonable estimates of oxygen fugacities, but generally yields subsolidus temperatures, suggesting re-equilibration of one or more phases during cooling.
\end{abstract}

\section{INTRODUCTION}

ILMENITE, $\mathrm{FETIO}_{3}$, occurs as an accessory phase in a wide variety of igneous and metamorphic rocks. In combination with other phases it has thermometric, barometric, and oxy-barometric significance (e.g. SPENCER and LINDSLEY, 1981; BOHLEN et al., 1983). However, thermodynamic data for ilmenite are incomplete. Heat-capacity measurements by SHOMATE et al. (1946) were only performed down to $51 \mathrm{~K}$. ROBIE (1965) and UlBricH and WALDBAUM (1976) noted that magnetic transitions below $50 \mathrm{~K}$ often make significant contributions to the entropies of transition metal phases. Because ilmenite has a paramagneticantiferromagnetic transition near $55 \mathrm{~K}$ (ISHIKAWA and AKIMOTO, 1957; STICKLER et al., 1967), heat-capacity measurements are needed to much lower temperatures for adequate extrapolation to $0 \mathrm{~K}$. We have remeasured the heat-capacity of ilmenite from 5 to $1000 \mathrm{~K}$ which allows more accurate calculation of phase relations of ilmenite and other minerals in the system Fe-Ti-O.

\footnotetext{
* Contribution No. 409 from the Mineralogical Laboratory,
} Dept. of Geological Sciences, and the Dept. of Chemistry, Univ. of Michigan, Ann Arbor, Ml 48109.

'Dept. of Geological Sciences, Univ. of Michigan, Ann Arbor, MI 48109.

${ }_{2}^{2}$ Present address: Dept. of Planetary Sciences, Univ. of Arizona, Tucson, AZ 85720 .

${ }^{3}$ U.S. Geological Survey, Mail Stop 959, Reston, VA 22092.

4 Dept. of Chemistry, Univ. of Michigan, Ann Arbor, MI 48109 .

${ }^{5}$ Dept. of Earth Sciences, Monash Univ., Clayton, Victoria, 3168, Australia.

${ }^{6}$ Faculty of Science, Departmento de Termologia, Facultad de Ciencias, Universidad de Zaragosa, 50009 Zaragosa, Spain.

${ }^{7}$ Dept. of Earth and Space Sciences, State University of New York, Stony Brook, NY 11794.

\section{SAMPLE DESCRIPTION}

A $6.9363 \mathrm{~g}$ sample of ilmenite was synthesized for lowtemperature adiabatic measurements. Merck "Ultrapure" grade $\mathrm{Fe}_{2} \mathrm{O}_{3}$, $\mathrm{TiO}_{2}$, and $\mathrm{Fe}$ metal reagents were used as starting materials. Stoichiometric mixtures of these reagents were reacted for 4 days in evacuated silica tubes at $1065^{\circ} \mathrm{C}$. The resultant material formed a dark grey powder. The lattice parameters of the sample were refined by powder diffaction methods using a scan speed of $1 / 4$ degree per minute and fluorite as an internal standard. Refinement was performed by leastsquares using 16 measured reflections on the hexagonal unit cell. The resulting values are $a=5.086(1) \AA$, and $c=14.077(7)$ $\AA$, close to those of the National Bureau of Standards (MORRIS et al., 1978; $\left.a_{0}=5.0884(2) \AA, c_{0}=14.0932(6) \AA\right)$. The slight differences may either be due to a small amount of $\mathrm{Fe}_{2} \mathrm{O}_{3}$ in our sample or $\mathrm{Ti}_{2} \mathrm{O}_{3}$ in the NBS standard.

Mössbauer spectra of ilmenite were obtained at room temperature by Dr. S. R. Bohlen (now at SUNY, Stony Brook) in W. Dollase's laboratory at the University of California, Los Angeles using a constant acceleration, mechanically driven Mössbauer spectrometer in order to check the material for the presence of $\mathrm{Fe}^{3+}$. Samples of $70-90 \mathrm{mg}$ were used with a $10 \mathrm{~m} \mathrm{Ci}{ }^{57} \mathrm{Co}$ in Pd source. Duplicate spectra were recorded in 512 channels of a multichannel analyzer using a velocity increment of $0.03 \mathrm{~mm}$ per channel. Counting times were suf ficient to obtain several million counts per channel and peak dips of approximately $10^{5}$ counts. The spectra were fitted with lorentzian doublets that in most cases were constrained to equal widths and areas for the low- and high-velocity components. Chi-squared and additional goodness-of-fit parameters (RUBY, 1973) were calculated for each fitted spectrum.

The Mössbauer spectrum of ilmenite consists of a single ferrous doublet and a very small, poorly defined ferric doublet that appears in the spectrum as a low intensity "shoulder" on the low-velocity part of the ferrous doublet. For the octahedrally coordinated ferrous iron in ilmenite the measured average isomer shift (relative to $\mathrm{Fe}^{0}$ ) and quadrupole splitting (IS $=1.058 \mathrm{~mm} / \mathrm{sec}, Q \mathrm{~s}=0.637 \mathrm{~mm} / \mathrm{sec}$ ) are similar to previously reported values (RUBY and SHIRANE, 1961; SYONO et al., 1981). Observed peak widths are $0.28 \mathrm{~mm} / \mathrm{sec}$. The intensity of the peaks attributable to ferric iron is so low that the location of the ferric doublet had to be constrained to be consistent with the isomer shifts and quadrupole splittings of octahedrally coordinated $\mathrm{Fe}^{3+}$ in other similar $\mathrm{Fe}$ phases in order to obtain 
convergence in the fitting procedure. The relative areas of the ferrous and ferric count dips suggest that approximately 3 $\pm 1.5 \%$ of the iron is present as $\mathrm{Fe}^{3+}$. A slight, but significant difference was noted in the areas of the two components of the ferrous doublet. At first this was thoughi to be the result of preferred orientation of the platy ilmenite grains. However, similar ferrous doublets with unequal areas are observed even after efforts have been made to eliminate the preferred orientation. Relaxation of the constraint of equal area results in a slightly better fit to the data but does not change the relative amounts of inferred $\mathrm{Fe}^{3+}$. The relative areas of the ferrous count dips differ by $3 \pm 0.1 \%$. The cause of this difference has not been determined.

\section{CALORIMETRIC TECHNIQUE}

Heat-capacity measurements were made in the Mark II adiabatic cryostat over the temperature range 5 to $350 \mathrm{~K}$. Cryostat construction and measurement-circuit calibration are described in WESTRUM et al. (1968). A gold-plated copper calorimeter (laboratory designation W-34) weighing $10.448 \mathrm{~g}$ with an internal volume of $6.567 \mathrm{~cm}^{3}$ and an axial entrant well for the thermometer assembly was used. The calorimeter was evacuated and then filled with 20 torr of He gas to enhance thermal contact and reduce equilibration times. A capsuletype platinum resistance thermometer (A-5) calibrated by the National Bureau of Standards and referred to the IPTS-48 temperature scale (STIMSON, 1961) above $90.18 \mathrm{~K}$ and the NBS 1955 provisional scale at lower temperatures was used for temperature measurements.

A molar mass of $151.7452 \mathrm{~g}$. corresponding to the formula $\mathrm{FeTiO}_{3}$ was used to calculate the apparent molar heat-capacity. Measured heat-capacity values were corrected for the heatcapacity of the empty calorimeter, which was measured separately, and for the differences in helium content between the empty and loaded calorimeter. Data are presented in Table 1 .

Heat-capacities from 340 to $1000 \mathrm{~K}$ were measured with a Perkin-Elmer differential scanning calorimeter (model DSC2) in R. A. Robie and B. S. Hemingway's laboratory at the U.S. Geological Survey in Reston, Virginia. A $31.952 \mathrm{mg}$ sample was measured as described by HEMINGWAY et al. (1981). Experimental and smoothed results are listed in Tables 2 and 3.

\section{RESULTS}

Smoothed low-temperature data (Table 4) show a distinet $\lambda$-type transition at approximately $57.2 \pm 0.1 \mathrm{~K}$ (Table 1), in fair agreement with the Néel point temperatures of $55 \mathrm{~K}$ determined by ISHIKAWA and AKIMOTO (1957) and $56 \mathrm{~K}$ determined by STICKLER et al. (1967). The differences are consistent with the small amount of ferric iron in our sample (ISHIKAWA and AKIMOTO, 1957), but the possible effects of $\mathrm{Ti}_{2} \mathrm{O}_{3}$ in either of the measured samples are unknown. Heatcapacity in this temperature region is composed of contributions from the crystal lattice, from the magnetic transition, and from electronic disorder (the Schottky contribution). The lattice heat-capacity of ilmenite was estimated from that of $\mathrm{MnTiO}_{3}$ (pyrophanite; STEFHENSON and SMrTH, 1968). The $C_{\mathrm{p}}$ (lattice) function for $\mathrm{MnTiO}_{3}$ was adjusted for mass and volume following the Lindemann relation:

$$
\Theta_{\mathrm{T}}=B\left[\frac{T_{\mathrm{m}}}{M V^{\prime 2 / 3}}\right]^{1 / 2}
$$

where $B$ is a constant, $T_{m}$ is the melting temperature, $M$ is the mean atomic weight, and $V$ the molar volume of the phase in question. For two minerals we obtain:

$\frac{\Theta_{\mathrm{T}}^{(11)}}{\Theta_{\mathrm{T}}^{(\text {(Pyro) }}}=\left[\frac{T_{\mathrm{m}}(\mathrm{II})}{T_{\mathrm{m}}(\text { Pyro })}\right)^{1 / 2} \cdot\left[\frac{M(\text { Pyro })}{M(\mathrm{II})}\right]^{1 / 2} \cdot\left[\frac{V \text { (Pyro })}{V(\mathrm{II})}\right]^{1 / 3}$.

The melting points of $\mathrm{FeTiO}_{3}$ and $\mathrm{MnTiO}_{3}$ are poorly known.

\begin{tabular}{|c|c|c|c|c|c|}
\hline$T$ & $C p$ & T & o & $r$ & $n$ \\
\hline K & $J /\left(m o I^{\prime} k\right)$ & $k$ & $J /(\infty)$ in $k)$ & $k$ & $\therefore \tan 1 \times$ \\
\hline Serles & es 1 & 196.35 & 78.09 & $15.91 \%$ & $\therefore \Delta$ \\
\hline 260.84 & 93.82 & 206.60 & 80.80 & 16.33 & 1.31 \\
\hline 270.91 & 93,74 & 216.67 & $83,3 k$ & 17.60 & $\therefore 54$ \\
\hline Serles & es 2 & Series & $s ?$ & 19.09 & $\therefore 64$ \\
\hline 258.60 & 86.29 & 47.61 & 24.24 & 20.61 & $\therefore 5 t$ \\
\hline 272.36 & 95.77 & 51.78 & 30,32 & 22.45 & $\div 3$ \\
\hline Series & es 3 & 55.27 & 35.95 & 24.40 & 4.5 \\
\hline 130.72 & $5^{4} .29$ & 55.75 & $36,8 ?$ & $26.5 \%$ & 52 \\
\hline 139.48 & 57,98 & 56.25 & 37.95 & 28.98 & $\varepsilon_{3}, b_{3}$ \\
\hline 148.32 & 61.58 & 56.36 & 38.45 & Fः $\rightarrow$ & 9.8 \\
\hline 157.29 & 64.98 & 56.66 & $39.6 !$ & $\gamma$ & 5.4 \\
\hline 166.50 & 68.51 & Series & 58 & 37.94 & 8.8 \\
\hline 176.19 & 71.88 & 54.09 & $33.5 \%$ & 49.46 & $\therefore 3 \mathrm{k}$ \\
\hline Series & es it & 54.61 & $36.5 \%$ & $45.0 \%$ & $\therefore \ldots$ \\
\hline 55.50 & $36.13^{*}$ & 55.12 & $35.57^{\circ}$ & 48.87 & .55 .80 \\
\hline 59.95 & 25.80 & Sertes & 99 & 52.13 & 30. \\
\hline 64.93 & 25.26 & 208.65 & 81.3 & $55.0 ?$ & 35,39 \\
\hline 70.10 & 26.75 & 219.65 & 83.94 & 55.57 & 36.19 \\
\hline 76.16 & 29.27 & 229.50 & 86.6 & 56.07 & 77.46 \\
\hline 84.44 & 33.35 & 239.60 & 89.12 & 56.55 & $89.1 \%$ \\
\hline Sertes & es 5 & 249.57 & $91.1:$ & $57.0 ?$ & 40.30 \\
\hline 50.96 & 28.59 & 259.93 & 93.20 & $5 ? .49$ & 28.20 \\
\hline 50.48 & $30.86^{\prime \prime}$ & $770.6 A$ & 95.20 & 57.99 & $70.26_{*}^{*}$ \\
\hline 53.91 & 33.34 & 281.28 & 97.44 & 58.51 & 26.58 \\
\hline 55.26 & 35.93 & 291.70 & 99.25 & 59.04 & 85.61 \\
\hline 56.54 & 39.09 & 302.10 & 100.81 & 59.57 & 25.05 \\
\hline 57.78 & 34.08 & 312.31 & 102.26 & 60.10 & $24.80 x$ \\
\hline 59.12 & $25.40^{\circ}$ & 322.42 & 104.00 & 60.62 & 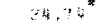 \\
\hline Series & & 332.46 & $106.1=$ & Serles: & $8:$ \\
\hline 57.83 & $32.06^{\circ}$ & 342.38 & 111.32 & 56,112 & $\left(263^{*}\right.$ \\
\hline 63.40 & 24,96 & Sertes & 310 & 56.32 & $30.2 \%$ \\
\hline 69.20 & $26.50^{\circ}$ & 5.32 & $0.34^{*}$ & $56.5:$ & 35.89 \\
\hline 75.55 & 29.00 & 7.24 & $0.00^{\circ}$ & 56.54 & $34.70^{\circ}$ \\
\hline 82.65 & 32.46 & 8.66 & 0.14, & $56.8 \%$ & $39.78^{*}$ \\
\hline 91.00 & 36.41 & 9.89 & $6.36^{\circ}$ & 57.05 & 40.17 \\
\hline 86.48 & 34.33 & Sertes & $s i$ & 57.23 & 30.54 \\
\hline 96.33 & 36.75 & 5.33 & $0.0:$ & 57.4 & 39.28 \\
\hline $106.5 i$ & 43.41 & 6.81 & 0.00 & 57.59 & 36.70 \\
\hline 115.93 & 47.77 & 7.72 & 0.00 & 57.78 & 32.83 \\
\hline 124.80 & 51.64 & 8.49 & 0.02 & 57.98 & 29.88 \\
\hline 132.78 & 55.15 & 9.16 & $0.02^{4}$ & $58.3 \%$ & $27.7\}$ \\
\hline 142.50 & 59.17 & 9.91 & 0.28 & 56,12 & 30.87 \\
\hline 152.83 & 63.31 & 10.80 & $0.4 ?$ & Serlew & $=1$ \\
\hline 163.83 & 67.44 & 11.88 & 0.55 & 54.44 & $39.0^{\circ}$ \\
\hline 175.02 & 71.38 & 12.91 & 0.69 & & \\
\hline 185.83 & 74.96 & 13.91 & 0.84 & & \\
\hline
\end{tabular}

* Data not ritted to smoothed curve

and depend on $f \mathrm{O}_{2}$ (LeVIN et al., 1969; LiNDSLEY, 1976), Because $T_{\mathrm{m}}$ for $\mathrm{FeTiO}_{3}$ and $\mathrm{MnTiO}_{3}$ are similar, they will be ignored. Using mean atomic weights and molar volumes from ROBIE et al. (1978) this yields:

$$
\frac{\theta_{\mathrm{T}}^{(1)}}{\theta_{\mathrm{T}}^{\left(\mathrm{P}_{\mathrm{rol}}\right)}}=1.00834
$$

The lattice heat-capacity of ilmenite is obtained by taking the estimated lattice $C_{p}$ of pyrophanite at some temperature $T_{1}$, multiplying $T_{1}$ by 1.00834 , and using the resulting $\left(C_{p}, T_{2}\right)$ as the $C_{p}$ model for ilmenite. The derived $C_{p}$ (lattice) for ilmenite is a good match for the measured data at high temperature (Fig. 1), but shows that there is significant non-lattice heat-capacity below $300 \mathrm{~K}$.

Non-lattice heat-capacity (excess heat-capacity) is caused by magnetic and electronic disordering. To calculate the total excess entropy $S^{\mathrm{ex}}, C_{\mathrm{p}}$ vs. $T$ was integrated using the Simpson 3-point method. For convenience in our calculations, below $20 \mathrm{~K} C_{\mathrm{p}}^{\mathrm{ex}}$ was assumed to follow the relation (L YON and WESTRUM, 1974):

$$
C_{\mathbf{p}}^{\mathbf{e x}}=T^{3}
$$

which yields:

$$
S^{0}(20)-S^{0}(0)=1 / 3 C_{\mathrm{p}}(20 \mathrm{~K})=0.63 \mathrm{~J} /(\mathrm{mol}-\mathrm{K})
$$

For numerical integration points were chosen at $5 \mathrm{~K}$ intervals from 20 to $50 \mathrm{~K}$. Across the transition, from 50 to $70 \mathrm{~K}$ points were chosen at $1 \mathrm{~K}$ increments, and points were spaced every $10 \mathrm{~K}$ from 70 to $300 \mathrm{~K}$. These calculations yield $S^{\mathrm{ex}}=19.12$ $J /(\mathrm{mol} \cdot \mathrm{K})$.

The magnetic contribution to excess entropy derives from disorder of magnetic moments of Fe atoms as the Neel tran- 
Table 2. Experlwental Migh-temperature heat capacities (DSC) cor lisente

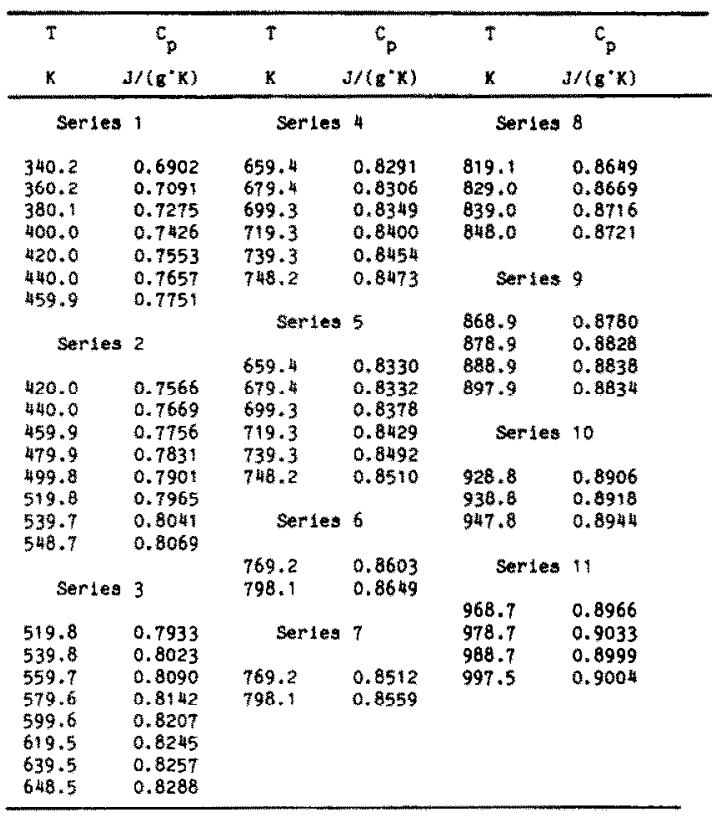

sition is crossed (GoPAL, 1966). For $\mathrm{FeTiO}_{3}$, which has one iron atom per mole, the total molar entropy from this transition is:

$$
S_{\mathrm{mag}}^{\mathrm{ex}}=R \ln 5=13.39 \mathrm{~J} /(\mathrm{mol} \cdot \mathrm{K}) \text {. }
$$

The remaining excess entropy is $5.73 \mathrm{~J} /(\mathrm{mol} \cdot \mathrm{K})$. This excess may be ascribed to disorder of electrons between orbitals (the Schottky effect; GOPAL, 1966; WOOD, 1981). At O K, the sixth $d$-electron in ferrous iron is assumed to reside in the lowest energy $d$-orbital. In ilmenite, distortion of the octahedra in which iron is found splits the $3 i_{28}$ orbitals into a lower energy pair $\left(d_{x z}\right.$ and $\left.d_{y z}\right)$ and a higher energy orbital $\left(d_{x y}\right)$. As temperature is raised, the sixth $d$-electron will tend to disorder over the lower energy orbitals. The Schottky effect generates an excess entropy of:

$$
S_{\text {Schottky }}^{\text {ex }}=R \ln 2=5.76 \mathrm{~J} /(\mathrm{mol} \cdot \mathrm{K}) .
$$

The close agreement suggests that we have a reasonable model of the lattice heat-capacity of ilmenite, and have accounted for all other entropy contributions below $360 \mathrm{~K}$. As the magnetic contribution cannot be calculated as a function of temperature, the possibility that this agreement is fortuitous cannot be evaluated.

Comparison of our heat-capacity data with that previously reported by SHOMATE et al. (1946) and later used by KELLEY and KNG (1961) and ROBIE et al. (1978) shows that at $50 \mathrm{~K}$, the lower limit of the older data, our results are $0.2 \mathrm{~J} /(\mathrm{mol} \cdot \mathrm{K})$ higher than they report, and at the peak of the transition our data are $2.9 \mathrm{~J} /(\mathrm{mol} \cdot \mathrm{K})$ higher than theirs. Between 150 and $298.15 \mathrm{~K}$ our results increased gradually to $0.7 \pm 0.1 \%$ higher than SHOMATE et al.'s, and our measured value of $S_{298}^{0}(108.9$ $\mathrm{J} /(\mathrm{mol} \cdot \mathrm{K}))$ is $3.0 \mathrm{~J}$ greater than the earlier value. This difference is due to our somewhat greater values of $C_{p}$ or all temperatures below $298 \mathrm{~K}$, our sharper magnetic anomaly, and to errors in their extrapolation from 50 to $0 \mathrm{~K}$.

Our calculated enthaipy for ilmenite is 1.9 percent higher at $1000 \mathrm{~K}$ than the value given by NAYLOR and COOK (1946) and used by ROBIE et al. (1978). The calorimeter used by Naylor and Cook was essentially the same as that used by O'BRIEN and KELLEY (1957). ANOVITz et al. (in prep.) have argued that the temperature scale used by $O^{\prime} B$ rien and Kelley for their drop calorimeter was in error by $7 \mathrm{~K}$ at $1000 \mathrm{~K}$. If we assume that the same systematic error existed in the calorimetric system of Naylor and Cook and correct for the assumed error in the temperature scale, the difference in the calculated enthalpy at $1000 \mathrm{~K}$ is reduced to 0.9 percent. This corrected result is within the combined experimental error in the data.

\section{PHASE EQUILIBRIA}

The ilmenite data presented above permit accurate calculation of the phase relations for the system FeTi-O. The following phases have been considered: iron (Fe), titanium ( $\mathrm{Ti})$, rutile $\left(\mathrm{TiO}_{2}\right)$, hongquiite (TiO), the Magneli phases $\mathrm{Ti}_{2} \mathrm{O}_{3}, \mathrm{Ti}_{3} \mathrm{O}_{5}, \mathrm{Ti}_{4} \mathrm{O}_{7}, \mathrm{Ti}_{5} \mathrm{O}_{9}, \mathrm{Ti}_{11} \mathrm{O}_{20}$, and $\mathrm{Ti}_{6} \mathrm{O}_{11}$, hematite $\left(\mathrm{Fe}_{2} \mathrm{O}_{3}\right)$, magnetite $\left(\mathrm{Fe}_{3} \mathrm{O}_{4}\right)$, wüstite $\left(\mathrm{Fe}_{0.947} \mathrm{O}\right)$, ilmenite $\left(\mathrm{FeTiO}_{3}\right)$, ulvöspinel $\left(\mathrm{Fe}_{2} \mathrm{TiO}_{4}\right)$, pseudobrookite $\left(\mathrm{Fe}_{2} \mathrm{TiO}_{5}\right)$, and ferropseudobrookite $\left(\mathrm{FeTi}_{2} \mathrm{O}_{5}\right.$ ). All calculations assume that these phases have stoichiometric cation/anion ratios. Possible non-

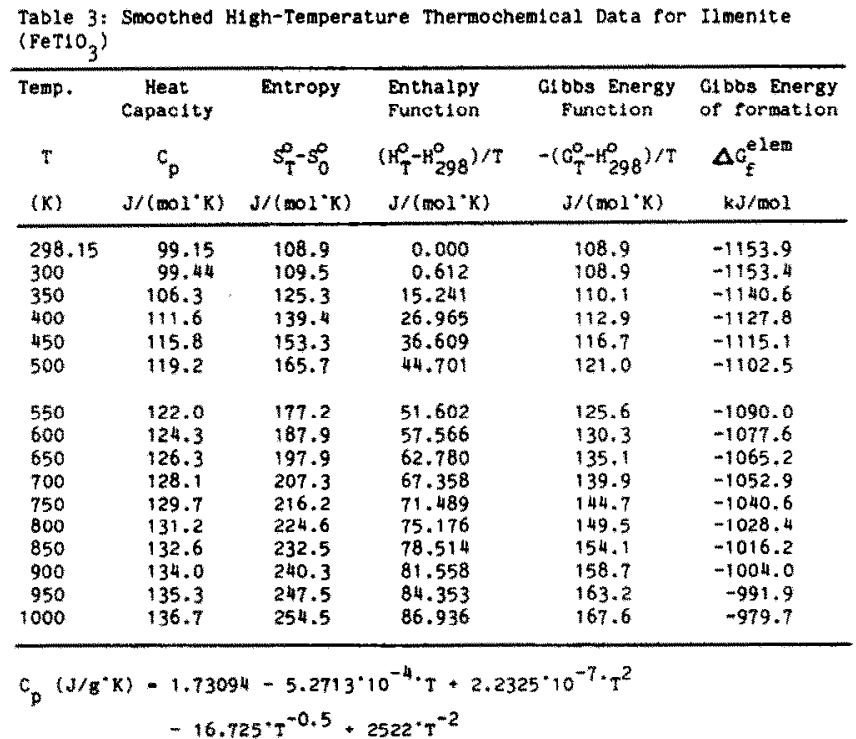




\begin{tabular}{|c|c|c|c|c|}
\hline$T$ & $c_{p}$ & $s_{T}^{0}-s_{0}^{0}$ & $\left(H_{T}^{O}-H_{O}^{O}\right) / T$ & $-\left(0_{\mathrm{T}}^{\circ}-\mathrm{H}_{\mathrm{O}}^{\circ}\right) / T$ \\
\hline K & $\mathrm{J} /\left(\operatorname{mol}{ }^{-} \mathrm{K}\right)$ & $\mathrm{J} /\left(\operatorname{mol}{ }^{*} \mathrm{~K}\right)$ & $J /\left(\operatorname{mol}{ }^{\circ} \mathrm{K}\right)$ & $\mathrm{J} /\left(\operatorname{mol} \mathrm{I}^{\circ} \mathrm{K}\right)$ \\
\hline 5 & $(0.04)$ & $(0.013)$ & $(0.05)$ & $(0.004)$ \\
\hline 10 & 0.31 & 0.10 & 0.79 & 0.025 \\
\hline 15 & 1.02 & 0.35 & 3.92 & 0.088 \\
\hline 20 & 2.33 & 0.81 & 12.04 & 0.205 \\
\hline 25 & 4.41 & 1.54 & 28.55 & 0.393 \\
\hline 30 & 7.35 & 2.59 & 57.57 & 0.669 \\
\hline 35 & 11.21 & 4.00 & 103.6 & 1.038 \\
\hline 40 & 15.85 & 5.79 & 171.0 & 1.515 \\
\hline 45 & 21.51 & 7.96 & 263.2 & 2.109 \\
\hline 50 & 27.30 & 10.49 & 383.9 & 2.816 \\
\hline 57.25 & 40.54 & 14.96 & 624,2 & 4.058 \\
\hline 65 & 25.25 & 18.30 & 827.7 & 5.573 \\
\hline 70 & 26.75 & 20.23 & 957.4 & 6.552 \\
\hline 80 & 31.12 & 24.07 & 1245 & 8.502 \\
\hline 90 & 35.93 & 28.02 & 1581 & 10.45 \\
\hline 100 & 40.60 & 32.05 & 1964 & 12.41 \\
\hline 110 & 45.09 & 36.13 & 2392 & 14.38 \\
\hline 120 & 49.51 & 40.24 & 2866 & 16.36 \\
\hline 130 & 53.87 & 44.38 & 3383 & 18.35 \\
\hline 140 & 58.15 & 48.23 & 3943 & 20.36 \\
\hline 150 & 62.26 & 52.68 & 4545 & 22.38 \\
\hline 160 & 66.15 & 56.83 & 5183 & 24.40 \\
\hline 170 & 69.75 & 60.95 & 5867 & 26.43 \\
\hline 180 & 73.05 & 65.02 & 6581 & 28.46 \\
\hline 190 & 76.11 & 69.04 & 7327 & 30.49 \\
\hline 200 & 78.99 & 73.01 & 8102 & 32.52 \\
\hline 210 & 81.71 & 76.94 & 8906 & 34.53 \\
\hline 220 & 84.27 & 80.79 & 9736 & 36.56 \\
\hline 230 & 86.73 & 84.60 & 10591 & 38.56 \\
\hline 240 & 89.08 & 88.37 & 11470 & 40.56 \\
\hline 250 & 91.25 & 92.05 & 12372 & 42.55 \\
\hline 260 & 93.34 & 95.65 & 13295 & 44.52 \\
\hline 270 & 95.20 & 99.20 & 14238 & 46.48 \\
\hline 273.15 & 95.85 & 100.33 & 14539 & 47.09 \\
\hline 280 & 97.11 & 102.72 & 15200 & 48.43 \\
\hline 290 & 98.91 & 106.15 & 16181 & 50.39 \\
\hline 298.15 & 100.25 & 108.91 & 16992 & 51.92 \\
\hline 300 & 100.54 & 109.54 & 17178 & 52.27 \\
\hline 310 & 102.05 & 112.84 & 18191 & 54.17 \\
\hline 320 & 103.47 & 116.11 & 19218 & 56.09 \\
\hline 330 & 105.44 & 119.33 & 20262 & 57.93 \\
\hline 340 & 109.62 & 122.55 & 21334 & 59.78 \\
\hline
\end{tabular}

stoichiometry and disorder should be carefully evaluated in phases formed at high temperatures before using the equilibria presented here. Sources for all thermodynamic data taken from the literature are listed in Table 5.

Phase equilibria presented here were calculated using thc FORTRAN program EQUILI (WALL and ESSENE, unpublished data) which is similar to that of SLAUGHTER et al. (1976). All calculations were performed using a second order approximation in which the thermal expansion of each phase at $P / T$ is assumed equal to that at 1 bar. $T$. and the compressibility of each phase at $P / T$ is assumed equal to that at $298 \mathrm{~K}$ and $P$.

The Gibbs energy of ilmenite was derived from published experiments (SHOMATE et al. 1946; LENEY and NoVOKHATSKII, 1964; TAYLOR and SCHMALZREID, 1964; LEVITSKIl et al., 1969, 1970; TAYLOR et al., 1972; SATO et al., 1973; MERRITT and TURNBULL, 1974; SAHA and BIGgar. 1974; SIMONS and WOER. MANN, 1978) on the reaction (Fig. 2):

$$
\begin{aligned}
& \text { Ilmenite }=\text { Iron }+ \text { Rutile }+\mathrm{O}_{2} \\
& \mathrm{FeTiO}_{3}=\mathrm{Fe}+\mathrm{TiO}_{2}+1 / 2 \mathrm{O}_{2} .
\end{aligned}
$$

The calculated position of the reaction fits the exper- imental data well, except for the data of TAYLOR 4 at (1972). As the amount of $\mathrm{Ti}_{2} \mathrm{O}_{3}$ component present in the experimental ilmenites is in most cases unknown. no correction for its effects could be made. and they were assumed to be minimal. The calculated Gibbs energy of formation is $-1153.9 \mathrm{~kJ} / \mathrm{mol}$ at STP ( I bar and $298.15 \mathrm{~K}$ ). This value is $5.9 \mathrm{~kJ} /$ mole smaller than that reported by ROBIE et al. (1978).

The $S_{298}^{0}$ value for ulvöspinel (titanomagnetite) (KELLEY and KING. 1961: $168.9 \mathrm{~J} /(\mathrm{mol} \cdot \mathrm{K})$ ) and used by ROBlE et al. (1978) contained $R$ In 2 added as "an allowance for randomness in the structure*. This is half the additional entropy expected from total disorder of iron and titanium over two octahedral sites, an arbitrary choice (KELLEY and KING, 1961). This was removed, and calculations were performed for both totally ordered and totally disordered ulvöspinel. Figure 3 shows experiments (SCHMAL $l l$ al., 1960; NovOKHATSKIl et al. 1966: WEBSTER and BRIGHT, 1966; TAYLOR et al. 1972; LeVITSKIl et al. 1972: SATO $e$ ? al. 1973; SAHA and BIGGAR, 1974; MERRTt and TURNBULL, 1974; SIMONS and WOERMANN, 978 ) on the reaction:

$$
\begin{gathered}
\text { Ulvöspinel }=\text { Ilmenite }+ \text { Iron }+O \\
\mathrm{Fe}_{2} \mathrm{TiO}_{4}=\mathrm{FeTiO}_{3}+\mathrm{Fe}+1 / 2 \mathrm{O}
\end{gathered}
$$

Derived values for the Gibbs energies of ordered and disordered ulvöspinel at STP are $-1413.9 \mathrm{~kJ} / \mathrm{mol}$ and $-1402.8 \mathrm{~kJ} / \mathrm{mol}$ respectively. The differences between the calculations for ordered (solid line) and disordered (dashed line) ulvöspinel are small (Fig. 3). Only results for the ordered phase will therefore be considered in further calculations.

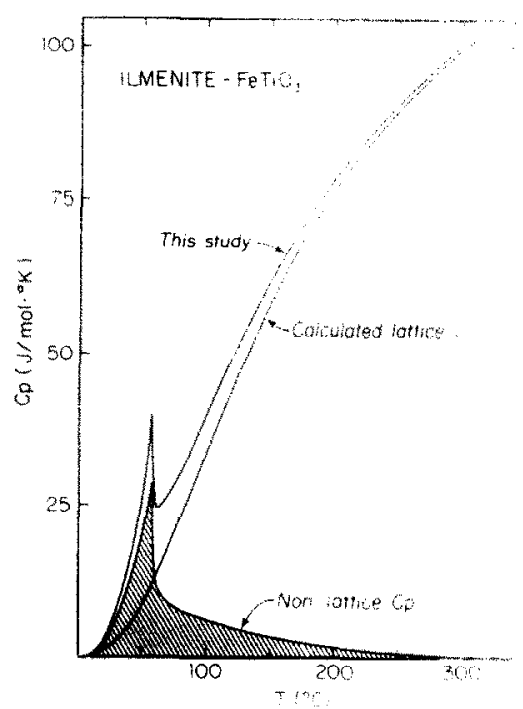

FIG. 1. Heat capacity of ilmenite as a function of temper. ature from 0 to $300 \mathrm{~K}$. The measured heat capacity, as well as calculated lattice and non-lattice contributions are shown. The shaded area was integrated to obtain non-lattices contributions to the total entropy. 
TABLE 5: Sources of data used in the calculations presented here

\begin{tabular}{|c|c|c|c|c|c|c|c|}
\hline PHASE & FORMULA & $A B R$ & YOL & TEXP & COMP & $\mathrm{s}$ & $\Delta \mathrm{G}$ \\
\hline$\alpha$-Iron & $\mathrm{Fe}$ & $a-f e$ & 1 & 1 & 1 & 1 & 1 \\
\hline$y$-Iron & $\mathrm{Fe}$ & $\gamma-\mathrm{Fe}$ & 1 & 1 & 1 & 1 & 1 \\
\hline$\alpha-T 1 \tan 1$ um & T1 & $a-T i$ & 2 & 3 & 4 & 2 & 2 \\
\hline$B-T 1 \tan 1$ um & Tí & $B-T 1$ & 2 & 3 & 4 & 2 & 2 \\
\hline$\alpha$-Hemat I te & $\mathrm{Fe}_{2} \mathrm{O}_{3}$ & a thim & 1 & 1 & 1 & 1 & 1 \\
\hline$B$-Hemat 1 te & $\mathrm{Fe}_{2} \mathrm{O}_{3}$ & $\mathrm{Bm} \mathrm{Hm}$ & 1 & 1 & 1 & 1 & 1 \\
\hline a-Magnetite & $\mathrm{Fe}_{3} \mathrm{O}_{4}$ & $a-M t$ & 1 & $:$ & 1 & \& & 1 \\
\hline 8 -Magnetite & $\mathrm{Fe}_{3} \mathrm{O}_{4}$ & $B-M t$ & 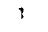 & 1 & 1 & 1 & 1 \\
\hline Wustit te & $\mathrm{Fe}_{0.947^{\circ}}$ & wu & 1 & 1 & 1 & $i$ & 1 \\
\hline $\mathrm{T}_{2} \mathrm{O}_{3}$ & $\mathrm{TI}_{2} \mathrm{O}_{3}$ & $\pi_{2} O_{3}$ & - & - & - & 2 & 2 \\
\hline $\mathrm{Ti}_{3} \mathrm{O}_{5}$ & $={ }_{3} 0_{5}$ & $2+30_{5}$ & - & $=$ & - & 2 & 2 \\
\hline $\mathrm{Ti}_{4} \mathrm{O}_{7}$ & $11_{4} 0_{7}$ & $w_{4} 0_{7}$ & - & - & - & 2 & 2 \\
\hline $\mathrm{Ii}_{5} \mathrm{O}_{9}$ & $\mathrm{II}_{5} \mathrm{O}$ & $\pi s_{59}$ & $*$ & - & - & 5* & 6 \\
\hline$T 1,1320$ & $\mathrm{Tl}, \mathrm{O}_{20}$ & $\pi_{11}, 0_{20}$ & - & - & - & 5* & 6 \\
\hline$T i_{6} O_{11}$ & $\mathrm{T1}_{6}{ }^{0} 11$ & $\mathrm{NH}_{6}{ }_{11}$ & - & - & - & 5* & 6 \\
\hline $\begin{array}{l}\text { Rutile } \\
. .\end{array}$ & $\mathrm{TiO}_{2}$ & Ru & 2 & 3 & 4 & 2 & 2 \\
\hline Ul vöspinel (Ord) & $\mathrm{Fe}_{2} \mathrm{THO}_{4}$ & Uv & 2 & 7 & 7 & $2^{*}$ & 5 \\
\hline UL vösplnel(D1s) & $\mathrm{Fe}_{2} \mathrm{THO}_{4}$ & Uv & 2 & 7 & 7 & 2* & 5 \\
\hline Ilmenite & $\mathrm{FeTHO}_{3}$ & II & 5 & 8 & 4 & 5 & 5 \\
\hline Pseudobrookite & $\mathrm{Fe}_{2} \mathrm{TlO}_{5}$ & Pyb & 2 & 9 & 9 & 2 & 5 \\
\hline Ferropseudobrookl te & $\mathrm{FeTI}_{2} \mathrm{O}_{5}$ & FpD & 10 & 9 & 9 & 5* & 5 \\
\hline
\end{tabular}

1) Robinson et al. (1982), 2) Robie et al. (1978), Skinner (1966), 4) Birch (1966), 5) This study, 6) Andurson and Khan (1970). 7) Compressibility set equal to that of magnetite, a) Thermal expansion set equal to hematite, 91 Thermal expansion and conpressibility set equal to that of ulvospinel, 10 ) Lindsley et

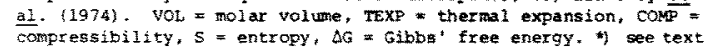

The Gibbs energy of pseudobrookite was derived from the reversal by HAGGERTY and LINDSLEY (1969) on the reaction:

$$
\begin{aligned}
\text { Pseudobrookite } & =\text { Hematite }+ \text { Rutile } \\
\mathrm{Fe}_{2} \mathrm{TiO}_{5} & =\mathrm{Fe}_{2} \mathrm{O}_{3}+\mathrm{TiO}_{2}
\end{aligned}
$$

at $585^{\circ} \mathrm{C}$ and 1 bar which yields $-1624.94 \mathrm{~kJ} / \mathrm{mol}$ at STP. NAVROTSKY (1975) notes that her measured enthalpy for pseudobrookite, together with the reversal of Haggerty and Lindsley, yields an entropy value in good agreement with the measured data. This may be fortuitous as neither order-disorder nor magnetic transition effects have been accounted for (NAVROTSKY, 1975). The entropy of pseudobrookite may contain $2 R \ln 2$ due to disorder, $2 R \ln 5$ due to magnetic effects, and $2 R \ln 2$ or $2 R \ln 3$ from Schottky effects depending on site distortions and crystal field effects. Because of the inherent uncertainties in the available data, and because of the agreement between the measured entropy data and Navrotsky's calculated entropy, all calculations in this paper will be based on the published entropy data without additions. Accurate low-temperature heat-capacity data are necessary if magnetic effects are to be understood and separated from the potential effects of disorder.

The entropy of ferropseudobrookite was estimated from the approximation (FYFE and VERHOOGEN, 1958):

$$
S^{0}(\mathrm{Fpb})=S^{0}(\mathrm{Il})+S^{0}(\mathrm{Psb})-S^{0}(\mathrm{Hm})+2.5 V^{0} \text {. }
$$

Above the Néel point of hematite the $S v s . T$ slopes of hematite and ilmenite are parallel. Below this temperature, however, the entropy of hematite changes more rapidly than that of ilmenite. In order to avoid systematic errors in the estimated entropy of ferropseudobrookite, the entropy of hematite below its Neel point was assumed to parallel that of ilmenite, offset by the difference in their entropies at the transition temper-

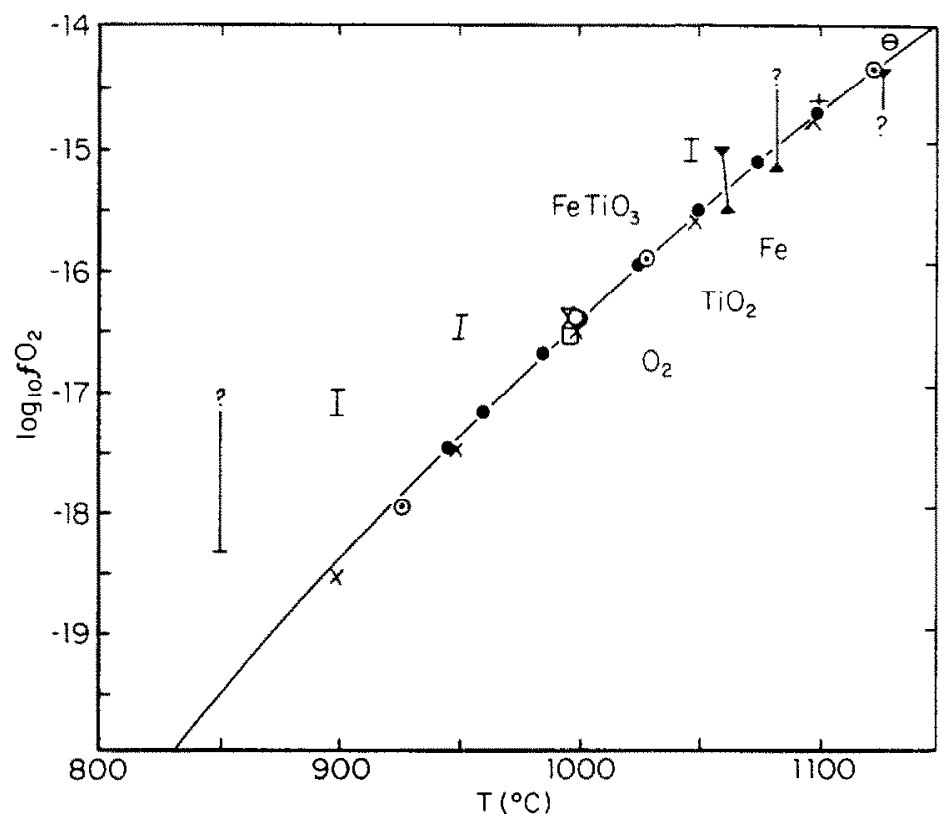

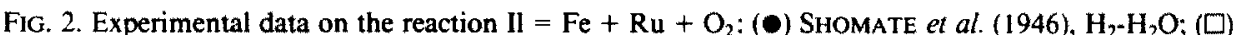
LENEV and NOVOKHATSKII (1964), CO-CO ${ }_{2} ;(+)$ TAYLOR and SCHMALZREID (1964), emf; $(\times)$ LEVITSKII

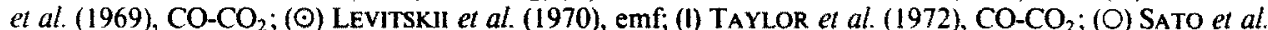
(1973), buffer unknown; $(\Theta)$ MERRIT and TURNBULl (1974), emf; $(\mathbf{X})$ SAHA and BIGGAR (1974), $\mathrm{H}_{2}$. $\mathrm{CO}_{2} ;(\bar{Z})$ SIMONS and WOERMANN (1978), $\mathrm{CO}-\mathrm{CO}_{2}$. The solid line represents the calculated position of this reaction. 


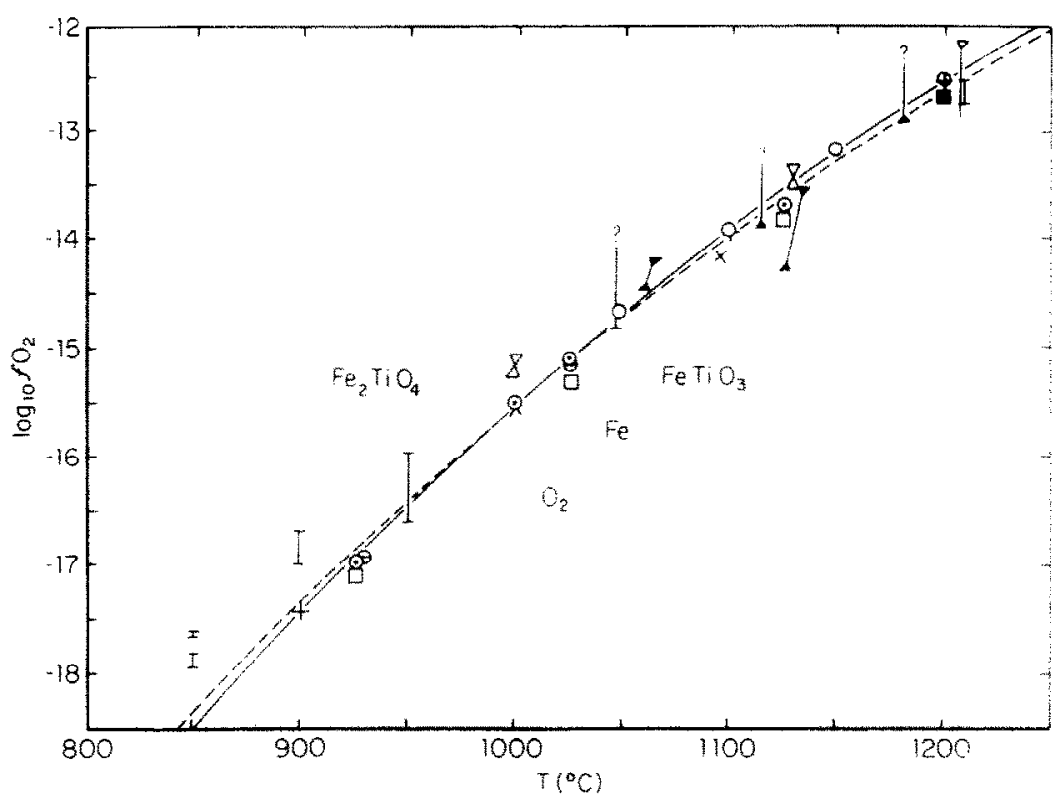

FIG. 3. Experimental data on the reaction $\mathrm{UV}=\| \mathrm{I}+\mathrm{Fe}+\mathrm{O}_{2} ;(\Theta)$ SCHMAL et al $(1960), \mathrm{CO}_{-} \mathrm{CO}_{2} ;+1$ TAYLOR and SCHMALZREID (1964), emf; (w) WEBSTER and BRIGHT (1966), $\mathrm{CO}-\mathrm{CO}_{2}$; (D) NOVOKHATSKII et al. (1966), CO-CO $\mathrm{CO}_{2}$ (1) TAYLOR et al. (1972), $\mathrm{CO}-\mathrm{CO}_{3}$; (O) SATO et al. (1973), buffer unknown; (X) MERRITT and TURNBULl (1974), emf; ( $\mathbf{X}$ ) SAHA and BIGGAR (1974), $\mathrm{H}_{2}-\mathrm{CO}_{2} ;(\odot)$ LEVITSKI et al. (1972),

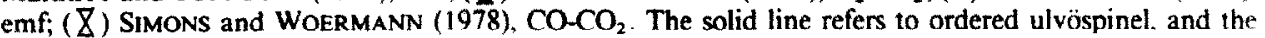
dashed line to disordered ulvöspinel.

ature for the estimation. This yields an estimated value of $S_{298}^{0}(\mathrm{Fpb})=156.1 \mathrm{~J} /(\mathrm{mol} \cdot \mathrm{K})$. As the entropy of ferropseudobrookite is based on that of pseudobrookite, ferropseudobrookite will also be treated as an ordered compound. As in the case of pseudobrookite, accurate low-temperature heat-capacity data are necessary if the effects of magnetic transitions and potential disorder are to be evaluated. The Gibbs energy at STP $\left(\Delta G_{298}^{0}(\mathrm{Fpb})=-2038.9 \mathrm{~kJ} / \mathrm{mol}\right)$ of ferropseudobrookite was derived from the reversal at $1140^{\circ} \mathrm{C}$ by $\mathrm{HAG}$. GERTY and LINDSLEY (1969) on the reaction:

$$
\begin{aligned}
\text { Ferropseudobrookite } & =I_{\text {Imenite }}+\text { Rutile } \\
\text { FeTi }_{2} \mathrm{O}_{5} & =\mathrm{FeTiO}_{3}+\mathrm{TiO}_{2} .
\end{aligned}
$$

The result of Haggerty and Lindsley has been chosen because the ferropseudobrookite used appeared to be free of a $\mathrm{Ti}_{3} \mathrm{O}_{5}$ component, while that of EL GORESY and WOERMANN (1976) contained 13.5 mole percent $\mathrm{Ti}_{3} \mathrm{O}_{5}$.

LINDSIEY (1983) noted that calculations in $\log f \mathrm{O}_{2}$ $T$ space can be displayed more clearly by plotting the results relative to a standard buffer curve. The position of the hematite-magnetite (HM) buffer:

$$
\begin{gathered}
\text { Magnetite }+\mathrm{O}_{2}=\text { Hematite } \\
4 \mathrm{Fe}_{3} \mathrm{O}_{4}+\mathrm{O}_{2}=6 \mathrm{Fe}_{2} \mathrm{O}_{3}
\end{gathered}
$$

has been calculated from the data of ROBINSON $e t$ al. (1982). Other reactions will be plotted relative to this buffer. In order to facilitate calculation of the absolute $\log f \mathrm{O}_{2}$ value from that given here we have fit $\log f \mathrm{O}_{2}$ for the HM buffer as calculated from ROBINSON $e t$ al.'s data to the following equations:

$$
\begin{aligned}
\log f \mathrm{O}_{2} & =-0.39824 \cdot T \\
& +-0.16378 \cdot 10^{7} / T^{2}+0.72703 \cdot 10^{-4} \cdot 7 \\
& +18.015 \cdot T^{0.5}-253.08(298.2-848.5 \mathrm{~K})
\end{aligned}
$$

$\log f \mathrm{O}_{2}=-0.21506 \cdot T+-0.49263 \cdot 10^{-4} \cdot F$

$$
+5.6010 \cdot 7^{0.5}(848.5-955.5 \mathrm{~K})
$$

$\log f \mathrm{O}_{2}=-0.13949 \cdot T+0.11822 \cdot 10^{-4} \cdot 7$

$$
+8.9815 \cdot T^{0.5}-167.75(955.5-1700 \mathrm{~K}) .
$$

\section{THE SYSTEM Ti-O}

Four minerals have been reported in the system $T_{1}$ $O$ : rutile, anatase, brookite, and hongquiite. Data of NAVROTSKY and KLEPPA (1967), SCHUILING and VINK (1967), JAMIESON and OLINGER (1968) and MITSUHASHI and KLEPPA (1979) suggests that anatase and brookite are metastable, and they will therefore be excluded from this discussion. An additional phase, $\mathrm{TiO}_{2}$-II has been synthesized at high pressures (DACHILLE and ROY, 1962; BENDELIANI et al, 1966; MCQUEEN et al., 1967; JAMIESON and OLINGER, 1968; DACHILLE et al., 1968; LINDSLEY, 1976) but its stability field has not been well located and no thermodynamic data are available. Hongquiite ( $\mathrm{TiO}$ ) has only been reported from one location, associated with platinum ores in garnet hornblende pyroxenites from the Tao district, China (Yu et al., 1974; FLEISCHER et al. 1976). 
The other phases in the Ti-O system are the Magneli phases, which have the generalized formula $\mathrm{Ti}_{n} \mathrm{O}_{2 n-1}$. Thermodynamic data exist for six of these phases: $\mathrm{Ti}_{2} \mathrm{O}_{3}, \mathrm{Ti}_{3} \mathrm{O}_{5}, \mathrm{Ti}_{4} \mathrm{O}_{7}, \mathrm{Ti}_{5} \mathrm{O}_{9}, \mathrm{Ti}_{11} \mathrm{O}_{20}$, and $\mathrm{Ti}_{6} \mathrm{O}_{11}$. Entropy data for the last three of these were estimated from $\mathrm{Ti}_{4} \mathrm{O}_{7}$ and rutile, and their Gibbs energies were calculated from the data of ANDERSON and KHAN (1970). As can be seen from its formula, $\mathrm{Ti}_{11} \mathrm{O}_{20}$ is not an end-member of the Magneli series, and Anderson and Khan suggest that it is an ordered intergrowth of $\mathrm{Ti}_{5} \mathrm{O}_{9}$ and $\mathrm{Ti}_{6} \mathrm{O}_{11}$.

Phase equilibria for this system at 1 bar are shown in Fig. 4. The lower stability of rutile forms the upper limit of reaction in this system. It lies $2.8 \mathrm{log}$ units below iron-wüstite at $1300 \mathrm{~K}$, and $10.6 \log$ units below iron-magnetite at $500 \mathrm{~K}$. The stabilities of $\mathrm{Ti}_{5} \mathrm{O}_{9}$, $\mathrm{Ti}_{11} \mathrm{O}_{20}$, and $\mathrm{Ti}_{6} \mathrm{O}_{11}$ are not shown in Fig. 4. Calculations based on the data of ANDERSON and KHAN (1970) suggest that $\mathrm{Ti}_{5} \mathrm{O}_{9}$ becomes stable above approximately $1300^{\circ} \mathrm{C}$, and that the lower stability limits of $\mathrm{Ti}_{11} \mathrm{O}_{20}$ and $\mathrm{Ti}_{6} \mathrm{O}_{11}$ lie at temperatures somewhat higher than that. As these temperatures represent long extrapolations of the estimated entropies of these phases, their stability fields cannot be predicted with any accuracy, and they have not been shown.

Most of the reactions shown in Fig. 4 lie well outside of usual terrestrial $f \mathrm{O}_{2}$ values (though see ESSENE and FISHER, 1984). Even lunar samples seem commonly to have formed within the stability field of rutile (EL GORESY et al., 1974; MAO et al., 1974). The reported occurrence of hongquiite is interesting as the upper limit of its stability as a pure phase lies 10 to $15 \mathrm{log}$ units below iron-wüstite. The hongquiite analysis given by $\mathrm{YU}$ et al. (1974), $\left(\mathrm{Ti}_{0.99} \mathrm{Fe}_{0.01}\right) \mathrm{O}$ suggests that solidsolution effects of cations will not account for its stabilization. The upper stability of hongquiite at $1000 \mathrm{~K}$ lies at $\log f \mathrm{O}_{2}=-36.4$. The data of ANOviTZ et al. (in prep.) show that almandine will break down to iron,

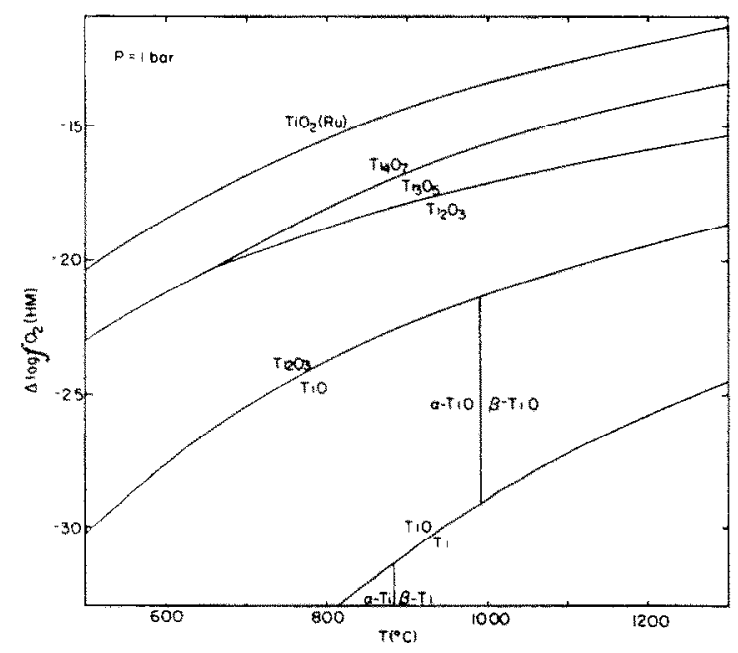

FIG. 4. Phase relations or the Ti-O system plotted relative to $\mathrm{fO}_{2}$ for the hematite-magnetite (HM) buffer, calculated from the data in Table 5. sillimanite and quartz at $\log f \mathrm{O}_{2}=-22.1$ at $1000 \mathrm{~K}$. Thus the activity of almandine in garnet in equilibrium with hongquiite can be no larger than $\log a_{\mathrm{Alm}}=-22.5$. Therefore, any garnet (and indeed any silicate) in equilibrium with TiO should have only some 10 atoms of Fe per mole of garnet! There is no indication of this in the brief description of silicates associated with hongquite (YU et al., 1974). We suspect that hongquiite has been mischaracterized or that it is completely out of equilibrium with its associated minerals. The possibility that hongquiite contains a light element other than oxygen, perhaps $\mathrm{N}$ or $\mathrm{C}$, should also be evaluated. The unit cell volumes of TiN (osbornite) and $\mathrm{TiC}$ are sufficiently close to $\mathrm{TiO}$ to suggest that the $\mathrm{X}$-ray patterns of these phases could be confused.

\section{THE SYSTEM Fe-Ti-O}

Phase relations in the system $\mathrm{Fe}-\mathrm{Ti}-\mathrm{O}$ are shown in Fig. 5 at 1 bar relative to hematite-magnetite. With the exception of the pseudobrookite reactions, the diagram is qualitatively symmetrical about the wüstite field. Reactions above this field are magnetite-bearing equivalents of iron-bearing reactions below it. Figure 5 has been calculated assuming that all phases remain pure end-members. Given the extensive solid-solutions present in magnetite, ilmenite, and pseudobrookite these curves only provide metastable limits on the positions of the actual reactions. Nevertheless, they provide a reference state from which the conditions of formation of phases containing solid-solutions inside and outside of the Fe-Ti-O system can be most easily calculated.

On the basis of a study of Apollo 17 samples EL GORESY et al. (1974) suggested that the reactions:

Ferropseudobrookite + Ulvöspinel $=$ llmenite

$$
\mathrm{FeTi}_{2} \mathrm{O}_{5}+\mathrm{Fe}_{2} \mathrm{TiO}_{4}=3 \mathrm{FeTiO}_{3}
$$

Ferropseudobrookite $=$ Ulvöspinel + Rutile

$$
2 \mathrm{FeTi}_{2} \mathrm{O}_{5}=\mathrm{Fe}_{2} \mathrm{TiO}_{4}+3 \mathrm{TiO}_{2}
$$

control the stability of ferropseudobrookite in lunar rocks. Calculation of the end-member reactions, however, shows them to be metastable with respect to reaction (12). Lunar samples of magnesian ferropseudobrookite ("armalcolite") contain approximately 50 percent replacement of $\mathrm{Fe}$ by $\mathrm{Mg}$. In addition, the ulvöspinels reported by El GORESY $a t$ al. are very chromian. The experimental work of LINDSI.FY et al. (1974) and of KESSON and LINDSLEY (1975) show that $\mathrm{Mg}^{2+}, \mathrm{Al}^{3+}, \mathrm{Cr}^{3+}$, and $\mathrm{Ti}^{3+}$ partition into ferropseudobrookite over ilmenite and rutile. This suggests that solid-solutions may stabilize reactions (15) and (16) in El GORESY ot al:s samples.

Pseudobrookite and ferropseudobrookite are rare minerals. Occurrences of pseudobrookite are reported in high temperature contact aureoles (e.g. AGRELL and LANGLEY, 1958; SMITH, 1965; RUMBLE, 1976), oxidized basalts (e.g. HAGGERTY, 1976), and rhyolites and ignimbrites (e.g. DEUTSCH and SOMAYAJULU, 1970; 


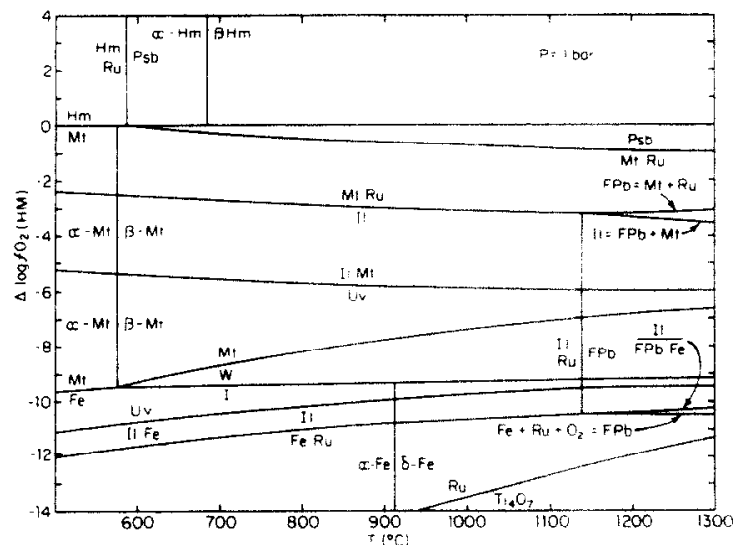

FIG. 5. Phase relations for the system $\mathrm{Fe}-\mathrm{Ti}-\mathrm{O}$ at 1 bar plotted relative to the hematite-magnetite buffer calculated from the data in Table 5.

LUFKIN, 1976; HaGgerTy, 1976). Ferropseudobrookite solid-solutions (armalcolite) are most commonly found as accessory phases in lunar basalts, but several terrestrial occurrences are known. The mineral "iserite" reported by JANOVSKY (1880) may be the first reported example. SCHALLER's (1912) analysis of iserite is close to the composition of ferropseudobrookite, but he considered it to be an intergrowth of iron and rutile. SMITH (1965) concluded that the material may be ferropseudobrookite, but a reexamination of the sample is necessary to resolve the problem. Other terrestrial occurrences of ferropseudobrookite have been reported by AGRELL and LONG (1960), HAGGERTY (1973, 1975. 1983), CAMERON and CAMERON (1973), VELDE (1975), RABER and HAGGERTY (1979), and PEDERSON (1979. 1981).

The limited terrestrial occurrences of pseudobrookite can be explained by its instability at low $\mathrm{fO}_{2}$, low $T$ and high $P$. Reactions (10) and (12) calculated as a function of temperature and pressure and contoured for $\log \mathrm{K}$ are shown in Fig. 6. Pseudobrookite is stable down to $585^{\circ} \mathrm{C}$ at 1 bar, but this minimum temperature increases rapidly with pressure. The minimum $f \mathrm{O}_{2}$ at which pseudobrookite is stable lies slightly below the hematite-magnetite buffer. Thus pseudobrookite should occur only in oxidizing, low pressure, high temperature rocks of appropriate composition.

Ferropseudobrookite occurrences will be even more restricted in terrestrial rocks. While ferropseudobrookite is stable at $f \mathrm{O}_{2}$ conditions commonly reported for terrestrial rocks, its low-temperature stability limit has a $d P / d T$ slope $\left(11.8 \mathrm{bars} /{ }^{\circ} \mathrm{C}\right)$ that is quite flat, similar to that for pseudobrookite $\left(8.9 \mathrm{hars} /{ }^{\circ} \mathrm{C}\right.$. in the hematite field). Unreasonably high temperatures would therefore be necessary to stabilize ferropseudobrookite in most rocks formed at medium to high pressures. The data of LiNDSLEY el al. (1974) and KESSON and LINDSLEY (1975) on the magnesian equivalent of reaction (13) suggest a steeper slope of 25 bars $/{ }^{\circ} \mathrm{C}$. FRIEL et al. (1977) studied the pressure-temperature stability of an armalcolite ( $50 \% \mathrm{Fe} / \mathrm{Fe}+\mathrm{Mg}$ ) and suggested a slope of $50 \mathrm{bars} /{ }^{\circ} \mathrm{C}$ with a $5 \mathrm{~kb}$ wide two-phase loop. These data suggest that reaction (12) should have a steeper slope than that found by FRIEL $e t$ al. rather than the flat slope calculated here. The difference may be due to the entropy estimate used for ferropseudobrookite, and clarification awaits careful measurements of its heat-capacity.

Pressure effects cannot, of course, explain the relative rarity of ferropseudobrookite in volcanic rocks. A survey of terrestrial basalts (BASALTIC VOLCANISM STUDY PROJECT, 1981) suggests that their average $f \mathrm{O}_{2}-T$ values lie within $\pm 2 \log f \mathrm{O}_{2}$ units of the QFM buffer at temperatures of up to $1200^{\circ} \mathrm{C}$. well within the stability field of ferropseudobrookite. Bulk composition may be a major controlling factor in the occurrence of ferropseudobrookite in terrestrial basalts.

\section{TIIERMOMETR}

The most widely used application of phase equilibria in the system Fe-Ti-O is undoubtedly magnetite-ilmenite thermometry (LINDSLEY, 1963; BUDDINGTON and LINDSLEY, 1964; SPENCER and LINDSLEY, 1981). Rumble (1971) and Powell and POWell (1977) noted that the temperatures derived may be represented as the temperature dependence of $\log \mathrm{K}$ for the ex. change reaction:

$$
\begin{aligned}
\text { Ilmenite }+ \text { Magnetite } & =\text { Hematite }+ \text { Ulvöspinel } \\
\mathrm{FeTiO}_{3}+\mathrm{Fe}_{3} \mathrm{O}_{4} & =\mathrm{Fe}_{2} \mathrm{O}_{3}+\mathrm{Fe}_{2} \mathrm{TiO}_{4}
\end{aligned}
$$

Once temperature is known, $f \mathrm{O}_{2}$ may be found from any of the following reactions:

$$
\begin{aligned}
\text { Magnetite }+\mathrm{O}_{2} & =\text { Hematite } \\
4 \mathrm{Fe}_{3} \mathrm{O}_{4}+\mathrm{O}_{2} & =6 \mathrm{Fe}_{2} \mathrm{O}_{3}
\end{aligned}
$$

Ulvöspinel $+\mathrm{O}_{2}=$ Ilmcnite + Magnetite

$$
\begin{aligned}
6 \mathrm{Fe}_{2} \mathrm{TiO}_{4}+\mathrm{O}_{2} & =6 \mathrm{FeTiO}_{3}+2 \mathrm{Fe}_{3} \mathrm{O}_{4} \\
\text { Ulvöspinel }+\mathrm{O}_{2} & =11 \text { menite }+ \text { Hematitc } \\
4 \mathrm{Fe}_{2} \mathrm{TiO}_{4}+\mathrm{O}_{2} & =4 \mathrm{FeTiO}_{3}+2 \mathrm{Fe}_{2} \mathrm{O}_{3}
\end{aligned}
$$

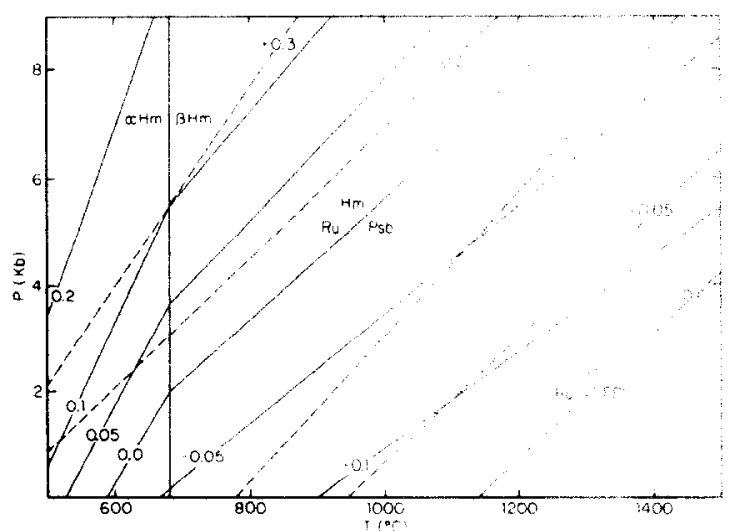

Fig. 6. Calculated position of the reactions $\mathrm{Psb}=\mathrm{Hm}$ $+\mathrm{Ru}$ (solid lines) and $\mathrm{Fpb}=\mathrm{Il}+\mathrm{Ru}$ (dashed lines) contoured for values of $\log \mathrm{K}$. 
Reaction (17) is extremely sensitive to values and equation used for the various thermodynamic parameters, as are most exchange reactions. Until these values are accurately known it is not possible to calibrate a thermometer in this manner without careful experiments.

The problem may be reformulated by noting that any two of reactions (18), (19), and (20) represent independent equations in $\log \mathrm{K}$, the third being the sum of the first two. At fixed $f \mathrm{O}_{2}$ and temperature these represent two equations in four unknowns as:

$\log \mathrm{K}(18)=6 \log \left(a_{\mathrm{Hm}}\right)-4 \log \left(a_{\mathrm{MV}}\right)-\log \mathrm{fO}_{2}$

$$
\begin{aligned}
\log \mathrm{K}(19)=6 \log \left(a_{11}\right) & +2 \log \left(a_{\mathrm{Mt}}\right) \\
& -6 \log \left(a_{\mathrm{Uv}}\right)-\log f \mathrm{O}_{2} \\
\log \mathrm{K}(20)=4 \log \left(a_{11}\right) & +2 \log \left(a_{\mathrm{Hm}}\right) \\
& -4 \log \left(a_{\mathrm{Uv}}\right)-\log f \mathrm{O}_{2} .
\end{aligned}
$$

If activity-composition relations are known along the magnetite-ulvöspinel and ilmenite-hematite joins the problem becomes one of four equations in four unknowns which may be solved explicitly. This approach may be used to obtain a diagram of the SPENCER and LINDSLEY (1981) type from thermodynamic data by contouring the calculated composition of phases from each join which are in equilibrium at a series of $f \mathrm{O}_{2-}$ $T$ values. Unfortunately, because of the equations used to formulate mixing models the problem is non-linear and must be solved numerically.

This analysis may be extended to the system pseudobrookite-ferropseudobrookite $v s$. ilmenite-hematite. The following reactions control the solid-solutions of the coexisting phases:

Pseudobrookite + llmenite

$$
\begin{array}{r}
=\text { Ferropseudobrookite }+ \text { Hematite } \\
\mathrm{Fe}_{2} \mathrm{TiO}_{5}+\mathrm{FeTiO}_{3}=\mathrm{FeTi}_{2} \mathrm{O}_{5}+\mathrm{Fe}_{2} \mathrm{O}_{3}
\end{array}
$$

llmenite $+\mathrm{O}_{2}$

$=$ Pseudobrookite + Ferropseudobrookite

$$
6 \mathrm{FeTiO}_{3}+\mathrm{O}_{2}=2 \mathrm{Fe}_{2} \mathrm{TiO}_{5}+2 \mathrm{FeTi}_{2} \mathrm{O}_{5}
$$

limenite $+\mathrm{O}_{2}=$ Hematite + Ferropseudobrookite

$$
8 \mathrm{FeTiO}_{3}+\mathrm{O}_{2}=2 \mathrm{Fe}_{2} \mathrm{O}_{3}+4 \mathrm{FeTi}_{2} \mathrm{O}_{5}
$$

Hematite + Ilmenite $+\mathrm{O}_{2}=$ Pseudobrookite

$$
2 \mathrm{Fe}_{2} \mathrm{O}_{3}+4 \mathrm{FeTiO}_{3}+\mathrm{O}_{2}=4 \mathrm{Fe}_{2} \mathrm{TiO}_{5}
$$

Hematite + Ferropseudobrookite $+\mathrm{O}_{2}$

$$
\text { = Pseudobrookite }
$$

$$
6 \mathrm{Fe}_{2} \mathrm{O}_{3}+4 \mathrm{FeTi}_{2} \mathrm{O}_{5}+\mathrm{O}_{2}=8 \mathrm{Fe}_{2} \mathrm{TiO}_{5} .
$$

Reactions (25) and (26) were arbitrarily chosen for obtaining the solution. The model of SPENCER and LINDSLEY (1981) was used for the hematite-ilmenite solution, and ferropseudobrookite-pseudobrookite solutions were assumed to be ideal, where $X_{\mathrm{Psb}}=X_{\mathrm{Fe}}-1$ $=a_{\mathrm{Psb}}$, and $X_{\mathrm{Fpb}}=1-X_{\mathrm{Psb}}$. GREY and MERRITT (1981) suggest that pseudobrookite solid-solutions are significantly non-ideal, but their data are insufficient to allow formulation of a more accurate model. Reactions (25) and (26) have been fit to the equations:

$\log \mathrm{K}(25)=2.3571 \cdot 10^{4} / T(\mathrm{~K})$

$$
-0.14081 \cdot P(\mathrm{~kb})-10.4861( \pm 0.07)
$$

$\log \mathrm{K}(26)=2.3237 \cdot 10^{4} / T(\mathrm{~K})$

$$
-0.13930 \cdot P(\mathrm{~kb})-10.5260( \pm 0.07) \text {. }
$$

If more accurate models for either solid-solution become available the results (Figs. 7 and 8 ) may be recalculated using these equations.

The region of $\Delta \log f \mathrm{O}_{2}-T$ space covered by this thermometer is shown in Fig. 7. As expected, pseudobrookite and hematite solutions dominate at high $\mathrm{fO}_{2}$ values, and ferropseudobrookite-ilmenite compositions at low $\mathrm{fO}_{2}$. Unfortunately, this thermometer allows large temperature variations with small changes in composition. Thus temperatures obtained from this calibration will be inaccurate, and it will be most useful as an oxygen barometer. The position of the hematiteilmenite solvus is calculated from the SPENCER and LINDSLEY (1981) solution model. The top of the solvus lies just below $700^{\circ} \mathrm{C}$, in agreement with the data of BURTON (1982, 1984) and of ESSENE et al. (1983). The

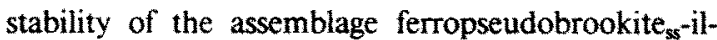
menite $_{\mathrm{ss}}$ is limited by reaction (12), which represents the lower bound to the region of applicability of this system to oxygen-barometry/thermometry (Fig. 7).

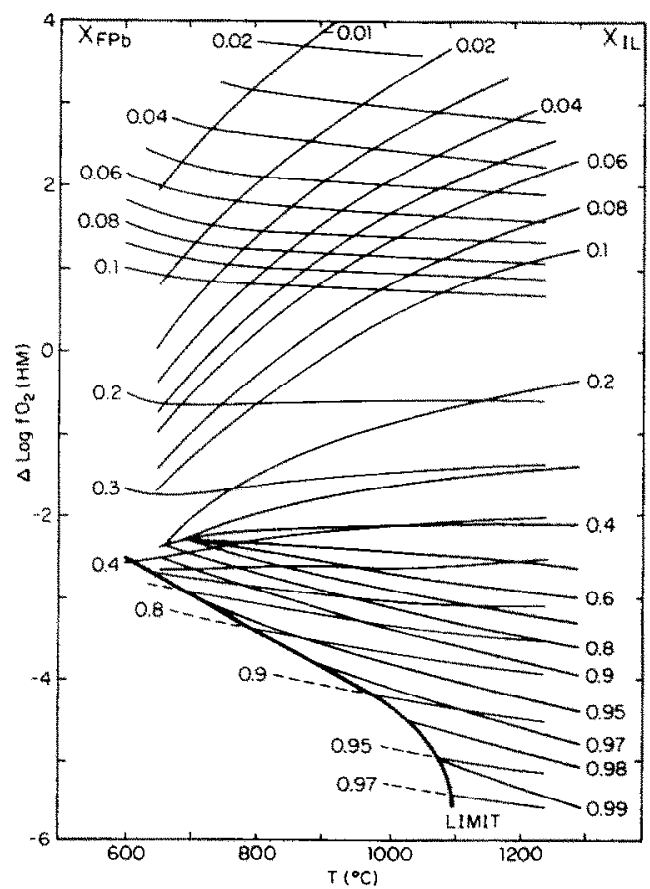

FIG. 7. Compositions of pseudobrookite in equilibrium with hematite contoured in $\Delta \log f \mathrm{O}_{2}$-T space, showing the compositions and $\Delta \log f \mathrm{O}_{2}$ values covered by this thermometer. Temperature and $\Delta \log f \mathrm{O}_{2}$ values are obtained from the point of intersection of the curves representing the compositions of the coexisting pseudobrookite and hematite solidsolutions. 


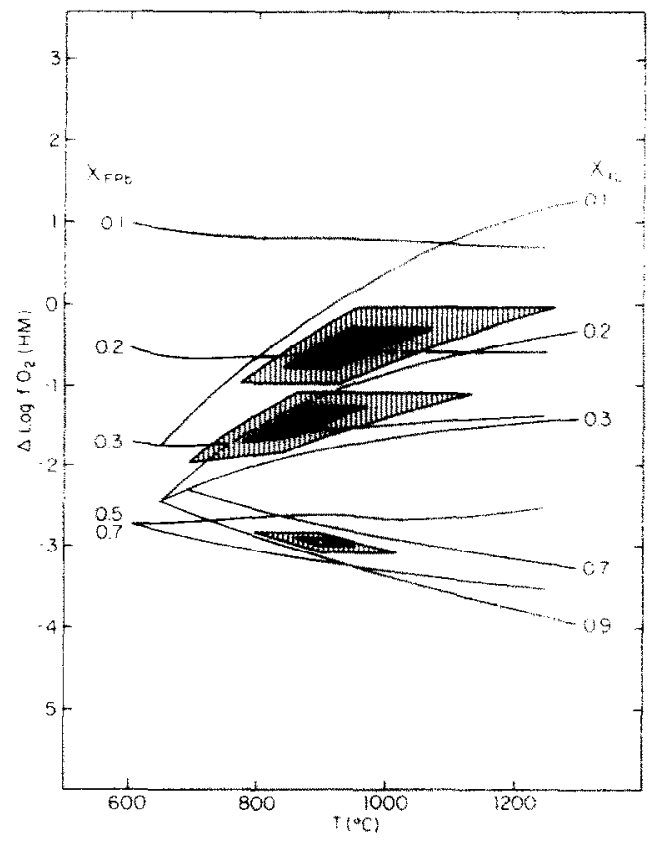

FiG. 8. Temperature and $\log f \mathrm{O}_{2}$ estimates for samples from Iceland and Hawaii reported by HAGGERTY (1971) and ANDERSON and WRIGHT (1972) respectively. Contours show the effects of \pm 2 (solid field) and 4 mole percent (hachured field) errors in the estimated mole fractions of ilmenite and ferropseudobrookite.

The calibration in Fig. (7) must be regarded as preliminary. An experimental calibration, similar to that for the magnetite-ilmenite thermometry is necessary to refine the model. Outside of the direct uses of this oxybarometer/thermometer, such a calibration would serve to provide an independent check on the activity/composition models of SPENCER and LINDSLEY (1981). Errors in their magnetite-ulvöspinel model may be tied to errors in their ilmenite-hematite model in such a way that they reproduce the data but are incorrect if applied to one solution in the absence of the other (SPENCER and LINDSLEY, 1981). Simultaneous modeling of both the magnetite-ilmenite and pseudobrookite-hematite thermometers should yield more precise activity/composition models for ilmenitehematite solutions, especially for hematite-rich compositions where calculations for Fig. 7 necessitated extrapolation of Spencer and Lindsley's model outside of the composition range to which it was fitted.

Unpublished experimental data (LINDSLEY, written commun., 1984) on the effects of solid-solution along the join ferropseudobrookite-pseudobrookite disagree somewhat with our calculation (Fig. 7). Three of four experiments in which the three-phase assemblage $\mathrm{Fpb}_{\mathrm{ss}}$ $\mathrm{Ilm}_{\mathrm{ss}}-\mathrm{Ru}$ is stable fall nicely within the three-phase field suggested by Fig. 7. A fourth experiment, however, at $750^{\circ} \mathrm{C}$ showed the three-phase assemblage stable at $X_{\mathrm{Fpb}}$ $=0.7$, while our calculations would limit this assemblage to compositions between $X_{\mathrm{Fpb}}=0.77$ and $X_{\mathrm{IIm}}$ $=0.95$. Because of the low angle of intersection of the isopleths with the "limit" curve, small errors in the position of either could account for the discrepancy As noted above, the solution of the equations leading to Fig. 7 requires that the activity of ferropseudobrookite is known at a given temperature and activity of pseudobrookite. In our model $a_{\mathrm{Fpb}}=X_{\mathrm{Fpb}}$ and $a_{\mathrm{Pst}}$ $=X_{\mathrm{Psb}}$ and therefore $a_{\mathrm{Fpb}}=1-\lambda_{\mathrm{psb}_{\mathrm{sb}}}$. If pseudobrookite solid-solutions exhibit a positive deviation from ideality, $a_{\mathrm{Fpb}}>X_{\mathrm{Fpb}}, a_{\mathrm{Psb}}>X_{\mathrm{Psb}}$ and $a_{\mathrm{Fpb}}>1 \cdots a_{\mathrm{F} s \mathrm{~b}}$. This would stabilize the three-phase assemblage over the $\mathrm{Fpb}_{\text {ss }}$ field relative to the positions of these helds calculated from the ideal model. bringing the calculated results into better agreement with Lindsley s experimental data.

The effects of pressure may be calculated from Eqns (24) and (25). For the pseudobrookite-hematite ther mometer, temperature increases approximately $10^{\circ} \mathrm{C}$ kbar and $\log \mathrm{fO}_{2}$ increases approximately $0.16 \mathrm{log}$ units/kbar over a $10 \mathrm{kbar}$ pressure range. If rutile is present pressure may be determined from the assem-

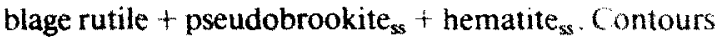
of $\log \mathrm{K}$ for reactions $(10)$ and (12) are shown in Fig. (6). The $P / T$ conditions for this assemblage must lic along one of these contours. Initial pressure and temperature estimates may be obtained from Figs. 6 and 7 and corrected by an iterative procedure. Because relatively small changes in $\log \mathrm{K}$ for reactions $(10)$ and (12) have large effects on the calculated pressures, the results obtained may not be very accurate, but pressure ranges of $\pm 1-2$ kbars should be obtainable.

\section{APPLICATIONS}

The magnetite-ilmenite thermometer/oxygen-barometer of BUDDINGTON and LINDSLEY (1964) and SPENCER and LINDSLEY (1981) has gained wide recognition through successful application to a wide va riety of igneous and metamorphic rocks. Other assenblages may also yield information on the $f \mathrm{O}_{2}-\gamma$ state of rocks. Applications involving the assemblages pseu. dobrookite-hematite and ferropseudobrookite-ilmenite will be considered below. Appropriate analyses from the references cited are listed in Table 6

\section{Ferropseudobrookite-ilmenite}

The assemblage ferropseudobrookite + imenite + iron \pm rutile has been reported from Apollo $17 \mathrm{sam}$ ples (EL Goresy et al., 1974: MAO el al. 1974). As noted by $\mathrm{MAO}$ et al. this assemblage must lie on the reaction:

Ferropseudobrookite + Iron $+\mathrm{O}_{2}=$ Ilmenite

$$
\mathrm{FeTi}_{2} \mathrm{O}_{5}+\mathrm{Fe}+1 / 2 \mathrm{O}_{2}=2 \mathrm{FeTiO}
$$

and on reactions (12) and (32):

$$
\begin{aligned}
& \text { Rutile + Iron }+\mathrm{O}_{2}=\text { Ferropseudobrookite } \\
& \qquad 2 \mathrm{TiO}_{2}+\mathrm{Fe}+1 / 2 \mathrm{O}_{2}=\mathrm{FeTi}_{2} \mathrm{O}_{5}
\end{aligned}
$$

SA ro et al. (1973) experimentally calibrated reactions (31) and (32), and found that they intersect at approx- 


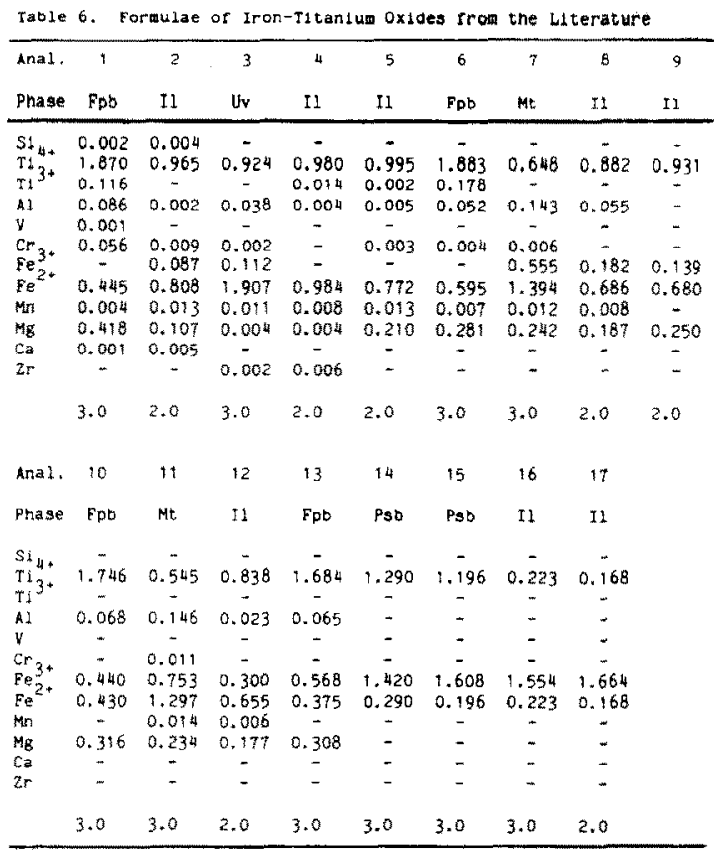

$(1-2)$ El Corøsy et al. $(1974) ;(3-4)$ Heyer and Boctor $(1974) ;(5-6)$ Pederson (1981): $(7-13)$ Anderson and Hright $(1972)_{i}(4+17)$ Haggerty spline and or have been renoralized to lntegral catlon totals.

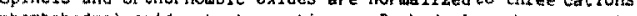
analyzed.

imately $1025^{\circ} \mathrm{C}$ rather than at $1140^{\circ} \mathrm{C}$ as suggested by the data of HAGGERTY and LINDSLEY (1969). This discrepancy may result from the very low angle of intersection of these reactions, or from the presence of a $\mathrm{Ti}_{3} \mathrm{O}_{5}$ component in the ferropseudobrookite used in SATO et al.'s experiments. Indeed, Simons and WOERMANN (1978) suggest that at these temperatures equilibrium ferropseudobrookite contains significant $\mathrm{Ti}_{3} \mathrm{O}_{5}$. Without a direct measurement on SA To et al.'s materials, however, no correction may be attempted.

Assuming that the four phases reported by MAO et al. (1974) represent an equilibrium assemblage, they can be used to fix $f_{\mathrm{O}_{2}}$ and $T$. As MAO et al. give no analyses, compositions must be estimated from other work on material from the Apollo 17 collections. Rutile and native iron are assumed to be pure, and ferropseudobrookite and ilmenite analyses were taken from the average grey armalcolite and primary ilmenite analyses reported by EL GORESY et al. (1974). The data of LINDSLEY et al. (1974) and KESSON and LINDSLEY (1975) suggest that this assemblage equilibrated at approximately $925 \pm 25^{\circ} \mathrm{C}$ at 1 bar. Assuming ideal mixing. $\log f \mathrm{O}_{2}=-14.7$, approximately $11 \mathrm{log}$ units below hematite-magnetite. LINDSLEY et al. (1974) and HAGGERTY (1983) note that the rutile in armalcolite + ilmenite + rutile assemblages may be due to subsolidus reequilibration, and thus the temperature and $f \mathrm{O}_{2}$ conditions calculated above probably represent a point in the cooling history of the rock, rather than the crystallization conditions.

A similar assemblage, ilmenite + armalcolite + rutile + iron is reported from a dacite (sample GGU 176466 , rock C) from Disko Island, Greenland (PEDERSON, 1981). The data of LINDSLEY et al. (1974) and of KESSON and LINDSLEY (1975) suggest a temperature of equilibration for this sample of approximately 950 $\pm 50^{\circ} \mathrm{C}$. The large inferred error is due to the uncertain effects of $\mathrm{Al}^{3+}, \mathrm{Cr}^{3+}$ and $\mathrm{Ti}^{3+}$ solid-solutions. This temperature is well below what Pederson infers from coexisting pyroxenes, and suggests that this assemblage equilibrated during subsolidus cooling. Assuming ideal mixing as before, $\log f \mathrm{O}_{2}=-17.5,10.7 \mathrm{log}$ units below hematite-magnetite.

MEYER and BOCTOR (1974) report the assemblage ulvöspinel + ilmenite + iron in rock 75035 (Apollo 17) which represents the reaction:

$$
\begin{aligned}
\text { Ulvöspinel } & =\text { Ilmenite }+ \text { Iron }+\mathrm{O}_{2} \\
\mathrm{Fe}_{2} \mathrm{TiO}_{4} & =\mathrm{FeTiO}_{3}+\mathrm{Fe}+1 / 2 \mathrm{O}_{2} .
\end{aligned}
$$

While this reaction does not permit temperatures to be calibrated, it fixes $f \mathrm{O}_{2}$ for this rock as a function of temperature. Reaction (33) yields:

$$
\log \mathrm{K}(33)=\log \left(a_{\mathrm{n}} \cdot a_{\mathrm{Fe}} / a_{\mathrm{Uv}}\right)+\log f \mathrm{O}_{2}
$$

For the compositions given by MEYER and BOCTOR (1974, Table 6):

$$
\log \left(a_{\mathrm{Il}} \cdot a_{\mathrm{Fe}} / a_{\mathrm{Uv}}\right)=0.03
$$

assuming ideal mixing. This implies that the rock equilibrated at $\mathrm{O}_{2}$ conditions nearly identical to those calculated from reaction (33) (Fig. 5).

\section{Pseudobrookite-hematite}

HAGGERTY (1971) graphically reports analyses for two pseudobrookite ss $_{\text {-hematite }}$ pairs in a specimen of Icelandic basalt. A sharp difference in the slopes of the reported tie-lines suggests different temperatures of equilibration or analytical errors. Haggerty notes that submicroscopic exsolutions of rutile make the reported analyses at best qualitative, which may account for the scatter in the tic-lines. Taking the most similar slopes allowed by the error brackets, the pseudobrookite-hematite geothermometer yields $T=900^{\circ} \mathrm{C}$ and $f \mathrm{O}_{2} 1.5$ $\log$ units below hematite-magnetite for the more ferrous pair, and $T=880^{\circ} \mathrm{C}, f \mathrm{O}_{2} 0.8 \mathrm{log}$ units below $\mathrm{HM}$ for the more ferric pair.

ANDERSON and WRIGHT (1972) report the assemblage ilmenite $_{s s}+$ pseudobrookite $_{s s}+$ magnetite $_{s s}$ in a basalt from Kilauea, Hawaii. While this cannot be an equilibration assemblage in the Fe-Ti-O system, it is probably stabilized by additional components. This assemblage allows the pseudobrookite-hematite system to be compared with the magnetite-ilmenite system. The magnetite-ilmenite pairs yield temperatures of $1100^{\circ} \mathrm{C}$ and $\Delta \log f \mathrm{O}_{2}=-5.0$, while the pseudobrookite $_{s s}$-hematite ss pairs yield $900^{\circ} \mathrm{C}$ and $\Delta \log f \mathrm{O}_{2}$ $=-3.0$. The source of this discrepancy remains unclear. The compositions of some of the oxide grains may have reset on cooling of the rock, the effects of solid-solutions outside of the Fe-Ti-O system may not 
have been properly accounted for, or there may be errors in the calibrations used.

Small analytical errors may lead to large errors in the temperatures calculated from pseudobrookite ${ }_{s s}$ hematite $_{\text {ss }}$ or ferropseudobrookite ${ }_{s s}$-ilmenite $_{s s}$ pairs. A good microprobe analysis with errors of \pm 2 percent of the amount present for the major elements $\mathrm{Fe}$ and $\mathrm{Ti}$ yields errors of 1 to 4 mole percent in the estimated mole fractions of ilmenite and ferropseudobrookite. Figure 8 shows the effects of variations of \pm 2 (solid shading) and 4 mole percent (hachured field) on the calculated temperature and $\Delta \log f \mathrm{O}_{2}$. While $\Delta \log$ $\mathrm{fO}_{2}$ varies by less than $\pm 0.5 \mathrm{log}$ units, temperature may vary by several hundred degrees. A typical magnetite/ilmenite pair (sample SR-31, BOHLEN and ESSENE, 1977), which yields a temperature of $690^{\circ} \mathrm{C}$ from the SPENCER and LINDSLEY (1981) thermometer, has an error of $\pm 100^{\circ} \mathrm{C}$ and $\pm 1 \log$ unit $\Delta \log f \mathrm{O}_{2}$ with a \pm 2 mole percent error in the measured ilmenite and magnetitc compositions. Users of either thermometer should therefore be careful to evaluate the potential effects of analytical errors on the results obtained.

Acknowledgements-Research was supported by NSF grant EAR-8009538 to E. J. Essene and E. F. Westrum Jr. Mary Schatz did the preliminary typing. Derwin Bell drafted the figures, and G. W. Metz helped with the computer programming. We would also like to thank D. H. Lindsley, R. A. Robie, and M. Sato for their helpful reviews. W. Dollase for permission to do the Mössbauer work in his laboratory, and Hanaa Zainel for her help on the low-temperature calorimetry.

Editorial handling: P. C. Hess

\section{REFERENCES}

AGRELL S. O. and LANGLEY J. M. (1958) The dolerite plug at Tievebulliagh near Cushendall, Co. Antrim. Proc. Roy. Irish Acad. Sect. B, 59, 63-127.

AGRELL S. O. and LONG J. V. P. (1960) The application of the scanning $\mathrm{X}$-ray microanalyzer in mineralogy. In $X-r a_{y}$ Microscopy and Microanalysis (eds. A. EUGSTROM, V. E. Cosslett and H. PATteE) 391-400. Elsevier, New York.

ANDERSON J. S. and KHAN A. S. (1970) Equilibria of intermediate oxides in the titanium-oxygen system. J. LessCommon Metals 22, 219-223.

ANDERSON A. T. JR. and WRIGHT T. L. (1972) Phenocrysts and glass inclusions and their bearing on oxidation and mixing of basaltic magmas, Kilauea volcano, Hawaii. Amer. Mineral. 57, 188-216.

BaSaltic Volcanism Study Project (1981) Basaltic Volcanism on the Terrestrial Planets. Pergamon Press, Inc., New York.

Bendeliani N. A., Popova S. V. and VereshChaGin L. F. (1966) New modification of titanium dioxide obtained at high pressures. Geochem. Internat. 3, 387-390.

BIRCH F. (1966) Compressibility: Elastic constants. In Handbook of Physical Constants (ed. S. P. ClARK JR.), pp. $97-$ 174. Geol. Soc. Amer. Mem 97.

BOHLEN S. R. and ESSENE E. J. (1977) Feidspar and oxide thermometry of granulites in the Adirondacks Highlands. Contrib. Mineral. Petrol. 62, 153-169.

BohleN S. R., WALL V. J. and BoetTChER A. L. (1983) Gcobarometry in granulites. In Kinetics and Equilibrium in Mineral Reactions (ed. S. K. SAXENA) 141-172. SpringerVerlag, New York.

BUDDINGTON A. F. and LindSI.FY D. H. (1964) Iron-titanium oxide minerals and synthetic equivalents. J. Petrol 5,310 357.

BURTON B. (1982) Thermodynamic analysis of the systems $\mathrm{CaCO}_{3}-\mathrm{MgCO}_{3}, \alpha-\mathrm{Fe}_{2} \mathrm{O}_{3}$ and $\mathrm{Fe}_{2} \mathrm{O}_{3}-\mathrm{FeTiO}$. Ph.D. thesis. State University of New York at Stony Brook.

BURTON B. (1984) Thermodynamic analysis of the sustem $\mathrm{Fe}_{2} \mathrm{O}_{3}-\mathrm{FeTiO}_{3}$. Phys. Chem. Mineral. 11. 132-140.

CAMERON K. L. and CAMERON M. (1973) Mineralogy of uttramafic nodules from Knippa quarry, near Uvalde. Texas. Geol. Soc. Amer. Abst. with Prog. 5, 566.

DACHILlE F. and RoY R. (1962) A new high pressure form of titanium dioxide (abstract). Bull Ceram. So tmer. 41, 225

Dachille F.. Simons P. Y. and RoY R. (1968) Pressuretemperature studies of anatase, brookite. rutile, and $\mathrm{TiO}_{2}$ II. Amer. Mineral. 53, 1929-1939.

DEUTSCH E. R. and SOMAYAJULU C. (1970) Paleomagnetism of Ordovician ignimbrites from Killary Harbour. Eire. Eanh Planet. Sci. Lett. 7, 337-345.

El Goresy A., RamDOHR P., MENDENBaCH O. and BerNHARDT H. J. (1974) Taurus-Liturow $\mathrm{TiO}_{2}$-rich basalts Opaque mineralogy and geochemistry. Proc. Lunar $S \mathrm{ci}$. Conf. 5th, Geochim. Cosmochim. Acta Suppl. 5, 6,7-652

El GORESY A. and WOERMANN E. (1976) Opaque minerals as sensitive oxygen barometers and geothermometers in lunar basalts. In Thermodynamics in Geology (ed. D. G. Fraser) 249-278. D. Reidel Publishing Co.. Boston.

ESSENE E. J. and FISHER D. C. (1984) Occurrence of natural iron silicides in a fulgurite and implications for extreme reduction during lightning strike fusion. Geol Soc Amer. Abst. with Prog. 16, 503.

ESSENE E. J., RICHARDSON S. V. and KESLER S. L. (1983)

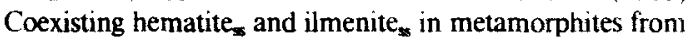
the Chapada copper district. Goias, Brazil: Constraints on the ilmenite-hematite solvus. Geol. Soc. Amer Abst. with Prog. 15, 568.

Fleischer M., Pabst A., Mandarino J. A. Chao G. Y and CABRI L. J. (1976) New mineral names. Amer. Mineral. 61, 174-186.

Friel J. J., HARKer I. and Ulmer G. C. (1977) Armalcolite stability as a function of pressure and oxygen fugacity. Geo. chim. Cosmochim. Acta 41, 411-418.

FYFE W. S. and VERHOOGEN J. (1958) General thermodynamic considerations. In Metamorphic Reactions and Metamorphic Facies (eds. W. S. FYFE, F. J. TURNER and J. VERHOOGEN) 21-51. Geol. Sos Amer Mem.73.

Gopal E. S. R. (1966) Specific Heals al Lon Temperalures. Plenum Press. New York.

GREY I. E. and MERRITT R. R. (1981) Stability relations in the pseudobrookite solid solution $\mathrm{Fe}_{2} \mathrm{Ti}_{3-3} \mathrm{O}_{3} . J$. Solid State Chem. 37, 284-293.

HaGGerTy S. E. (1971) High-temperature oxidation of itmenite in hasalts. Carnegie Inst. Wash. Yearb. 70, 165176.

HAGGERTY S. E. (1973) Armalcolite and genetically associated opaque minerals in the lunar samples. Proc. Lunar $S_{c i}$ Conf. 4th, Geochim. Cosmochim. Acta Suppl. 4, 777, 797.

HAGGERTY S. E. (1975) The chemistry and genesis of opaque minerals in kimberlites. Phys. Chem. Earth 9, 295-307.

HAGGERTY S. E. (1976) Opaque mineral oxides in terrestrial rocks. In Oxide Minerals, MSA Review's in Mineralogl, Vol. 3 (ed. D. RuMBLE III), pp. 101-300.

HaGgerty S. E. (1983) The mineral chemistries of new trtanates from the Jagersfontein kimberlite, South Africa: Implications for metasomatism in the upper mantle. Geo. chim. Cosmochim. Acta 47, 1833-1854.

HAGGERTY S. E. and LINDSLEY D. H. (1969) Stability of the pseudobrookite ( $\mathrm{Fe}_{2} \mathrm{TiO}_{5}$-ferropseudobrookite ( $\mathrm{FeTi}_{2} \mathrm{O}_{5}$ ) series. Carnegie Inst. Wash. Yearb. 68, 247-249

Hemingway B. S., KRupka K. M. and Robie R. A. (1981) Heat-capacities of the alkali feldspars between 350 and 1000 $K$ from differential scanning calorimetry; the thermodynamic functions of the alkali feldspars from 298.15 to 1400 
$\mathrm{K}$ and the reaction quartz + jadeite $=$ analbite. $A$ mer. Mineral. 66, $1205-1215$.

ISHIKAWA Y. and AKIMOTO S. (1957) Magnetic properties of the $\mathrm{FeTiO}_{3}-\mathrm{Fe}_{2} \mathrm{O}_{3}$ solid-solution series. J. Phys. Soc. Japan 12, 1083-1098.

JAMIESON J. C. and OLINGER B. (1968) High pressure polymorphism of titanium dioxide. Science 161, 893-895.

JANOVSKY J. V. (1880) Über Niobit und ein neues Titanit von Isergeberge. Akad. Wiss. Wien. Kl. 80, 39.

KeLLEY K. K. and KING E. G. (1961) Contributions to the data on theoretical metallurgy XIV. Entropies of the elements and inorganic compounds. U.S. Bur. Mines Bull 592.

KESSON S. E. and LINDSLEY D. H. (1975) The effects of $\mathrm{Al}^{3+}$, $\mathrm{Cr}^{3+}$ and $\mathrm{Ti}^{3+}$ on the stability of armalcolite. Proc. Lunar Sti. Conf 6th, Geochim. Cosmochim. Acta Stupl 6, 911920.

LENEV L. M. and NovoKHATSKII I. A. (1964) Thermodynamic characteristics of a metatitanate of Fe. Izv. Akad. Nauk. SSSR, Met. i Gorn. Delo. 4, 87-90.

LeVIN E. M., Robins C. R. and MCMurdie 11. Г. (1969) Phase Diagrams for Ceramists, 1969 Supplement (ed. M. K. RosLer). Amer. Ceram. Soc. Inc.

Levitskil V. A., Lebedev B. G., Popov S. G. and RatianI D. D. (1969) Thermodynamic properties of binary oxide systems at high temperatures I. Equilibrium of ilmenite $\left(\mathrm{FeTiO}_{3}\right)$ with carbon monoxide-carbon dioxide mixtures. Russ. J. Phys. Chem. 43, 2944.

LEVITSKII V. A., POPOV S. G. and RATIANI D. D. (1970) Thermodynamic properties of binary oxide systems at el evated temperatures II. Determination of the Gibbs free energies of formation of iron titanate from the oxides by an electrochemical method. Russ. J. Phys. Chem. 44, 749750 .

Levitskil V. A., Popov S. G., Ratiani D. D. and LebedeV B. G. (1972) Thermodynamic properties of iron orthosilicate, metatitanate, aluminate, and chromite at high temperatures. Termodin. Kinet. Prosessov. Vastanov. Metal. Mater. Konf. Chem. Abst. 79, 10582.

LINDSLEY D. H. (1963) Fe-Ti oxides in rocks as thermometers and oxygen barometers. Carnegie Inst. Wash. Yearb. 62, $60-66$.

LINDSLEY D. H. (1976) Experimental studies of oxide minerals. In Oxide Minerals, MSA Reviews in Mineralogy; Vol. 3 (ed. D. RUMBLE III).

LINDSLEY D. H. (1983) Experimental calibration of the equilibrium: $\mathrm{Fc}_{2} \mathrm{SiO}_{4}+2 \mathrm{FeTiO}_{3}=2 \mathrm{Fe}_{2} \mathrm{TiO}_{4}+\mathrm{SiO}_{2}$. Geol. Sci. Amer. Abst. with Prog. 15, 628.

LindSLey D. H. KesSON S. E., HaRTZMANN M. J. and Cushman M. K. (1974) The stability of armalcolite: Experimental studies in the system Mg-Fe-Ti-O. Proc. Lunar Sci. Conf. 5th. Geochim. Cosmochim. Acta Suppl. 5, 521534.

LUFKIN J. L. (1976) Oxide minerals in microlitic rhyolite, Black Range. New Mexico. Amer. Mineral. 61, 425-430.

LYON W. G. and Westrum E. F. JR. (1974) Heat capacities of zinc lungstate and ferrous tungstate from 5 to $550 \mathrm{~K} . J$. Chem. Therm. 6, 763-780.

MAO H. K.. El Goresy A. and BeLL P. M. (1974) Evidence for extensive chemical reduction in lunar regolith samples from the Apollo 17 site. Proc. Lunar Sci. Conf. 5th, Geochim. Cosmochim. Acta Suppl. 5, 673-683.

MCQUEen R. G., Jamieson J. C. and MARSH S. P. (1967) Shock-wave compression and $X$-ray studies of titanium dioxide. Science 155, 1401-1404.

MerRitT R. R. and TURNBULl A. G. (1974) Solid-state cell study of oxygen activities in the iron-titanium-oxygen system. J. Solid State Chem. 10, 252-259.

MEYeR H. O. A. and Boctor N. Z. (1974) Opaque mineralogy: Apollo 17, rock 75035. Proc. Lunar Sci. Conf. 5th, Geochim. Cosmochim. Acta Suppl. 5, 707-716.

MitsuhashI T. and KLEPPA O. J. (1979) Transformation enthalpies of the titanium oxide polymorphs. $J$. Amer. Ceram. Soc. 62, 356-357.
Morris M. C. McMurdie H. F., Evans E. H., RaretzkiN B.. PARKER H.S. and PANGIOTOPOULIS N. C. (1978) Standard X-ray powder diffraction patterns. U.S. National Bureau Standards Monogr. 25(15), 34.

NAVROTSKY A. (1975) Thermodynamics of formation of some compounds with the pseudobrookite structure and of the $\mathrm{FeTi}_{2} \mathrm{O}_{5}-\mathrm{Ti}_{3} \mathrm{O}_{5}$ solid-solution series. Amer. Mineral. 60, 249-256.

NAVROTSKY A. and KLePPA O.J. (1967) Enthalpy of the anatase-rutile transformation. J.Amer. Ceram. $S o c$. $\mathbf{5 0}, 626$.

NAYLOR B. F. and CoOK O. A. (1946) High-temperature heat contents of the metatitanates of calcium, iron, and magnesium. Amer. Chem. Soc. J. 68, 1003-1005.

NOVOKHATSKII I. A., LeNEV L. M. and SAvinSKayA A. A. (1966) Thermodynamic functions of compound formation in the FeO-TiO 2 system. Izv. Vysokikh. Uchebn. Zavendenii. Chern. Met 9, 5-13,

O'BRIEN C. 3. and KELLEY K. K. (1957) High-temperature heat contents of cryolite, anhydrous aluminum fluoride and sodium fluoride. J. Amer. Chem. Soc. 79, 5616-5618.

PEDERSON A. K. (1979) A shale buchite xenolith with Alarmalcolite and native iron in a lava from Asuk, Disko, Central West Greenland. Contrib. Mineral. Petrol 69, 8394.

PEDERSON A. K. (1981) Armalcolite-bearing Fe-Ti oxide assemblages in graphite-equilibrated salic volcanic rocks with native iron from Disko. Central West Greenland. Contrib. Mineral. Peirol. 77, 307-324.

POWELL. R, and POWELL M. (1977) Geothermometry and oxygen barometry using coexisting iron-titanium oxides: A reappraisal. Mineral. Mag. 41, 257-263.

RABER E. and HAGGERTY S. E. (1979) Zircon-oxide reactions in diamond-bearing kimberlites. In Kimberlites, Diatremes, and Diamonds: Their Geology. Peirology, and Geochemistry (ed. F. R. BOYD and H. O. A. MEYER), pp. 229-240.

RoBiE R. A. (1965) Heat and free energy of formation of herzenbergite. troilite, magnesite, and rhodochrosite calculated from equilibrium data. U.S. Geol. Sur. Prof. Pap $525-D .65-72$.

RoBie R. A. HEMINGWAY B. S. and FISHER J. R. (1978) Thermodynamic properties of minerals and related substances at $298.15 \mathrm{~K}$ and 1 bar ( $10^{5}$ Pascals) pressure and at higher temperatures. U.S. Geol. Surv. Bull. 1452

ROBINSON G. R. JR.. HASS J. L. JR., SCHAFER C. M. and HASELTON H. T. JR. (1982) Thermodynamic and thermophysical properties of selected phases in the $\mathrm{MgO}_{-} \mathrm{SiO}_{2}$. $\mathrm{H}_{2} \mathrm{O}-\mathrm{CO}_{2}, \mathrm{CaO}-\mathrm{Al}_{2} \mathrm{O}_{3}-\mathrm{SiO}_{2}-\mathrm{H}_{2} \mathrm{O}-\mathrm{CO}_{2}$, and $\mathrm{FeO}-\mathrm{Fe}_{2} \mathrm{O}_{3}-\mathrm{SiO}_{2}$ chemical systems with special emphasis on the properties of basalts and their mineral components. U.S. Geol. Surv. Open-File Rept 83-79.

RUBY S. L. (1973) Why misfit when you already have $X^{2}$ ? Mössbauer Effect Methodology 8, 263-277.

Ruby S. L. and ShIRANe G. (1961) Magnetic anomaly in $\mathrm{FeTiO}_{3}-\mathrm{Fe}_{2} \mathrm{O}_{3}$ system by Mössbauer effect. Phys. Rev. 23, $1239-1240$.

RUMBLE D. III (1971) Thermodynamic analysis of phase equilibria in the system $\mathrm{Fe}_{2} \mathrm{TiO}_{4}-\mathrm{Fe}_{3} \mathrm{O}_{4}-\mathrm{TiO}_{2}$. Carnegie Inst. Wash. Yearb. 69, 198-207.

RUMBLE D. III (1976) Oxide minerals in metamorphic rocks. In Oxide Minerals, MSA Reviews in Mineralogy, Vol. 3 (ed. D. RUMBLE III).

SAHA P. and BIGGAR G. M. (1974) Subsolidus reaction equilibriums in the system iron-titanium-oxygen. Ind. J. Earth Sci. 1, $43-54$.

Sato M., Hickling N. L. and MClane J. E. (1973) Oxide fugacity values of Apollo 12, 14. and 15 lunar samples and reduced state of lunar magmas. Proc. Lunar Sci. Conf. $4 \mathrm{th}$, Geochim. Cosmochim. Acta Suppl. 4, 1061-1079.

SCHALLER W. T. (1912) The rutile group minerals. U.S. Geol. Surv, Bull. 1509, 8-39.

SCHULING R. D. and VINK B. W. (1967) Stability relations of some titanium minerals. Geochim. Cosmochim. Acta 31, $2399-2411$.

SCHMAL N. G., Frisch B. and Hargarter E. (1960) Phase 
relations for the Fe-Ti-O system. Z. Anorg. Chem. 305, 4054.

Shomate C. H., Naylor B. F. and Boericke F. S. (1946) Thermodynamic properties of ilmenite and selective reduction of iron in ilmenite. U.S. Bur. Mines Rept. Inv 3864.

SIMONS B. and WOERMANN E. (1978) Iron-titanium oxides in equilibrium with metallic iron. Contrib. Mineral. Petrol 66, 81-89.

SKINNER B. J. (1966) Thermal expansion. In Handbook of Physical Constants (ed. S. P. CLARK JR.). pp. 76-96. Geol Soc. Amer. Mem. 97.

SLAughter J., WALL V. J. and KerRick D. M. (1976) API computer programs for thermodynamic calculations of equilibria in $P-I-X_{\mathrm{CO} 2}$ space. Contrib. Mineral. Petrol. 54. $157-171$

SMrth D. G. W. (1965) The chemistry and mineralogy of some emery-like rocks from Sithean Sluaigh. Strachur. Agyllshire. Amer. Mineral. 50, 1982-2022.

SPENCER K. J. and LINDSLEY D. H. (1981) A solution model for coexisting iron-titanium oxides. Amer. Mineral. 66. $1189-1201$.

StEPHENSON C. C. and SMITH D. (1968) Heat capacity of manganese titanate from 30 to $300 \mathrm{~K} . J$. Chem. Phvs. 49 , $1814-1818$.

STICKLER J. J., KeRN S., WOLD A. and Heller G. S. (1967) Magnetic resonance and susceptibility of several ilmenite powders. Phys. Rev. 164, 765-767.

STIMSON H. E. (1961) Text revision of the international temperature scale of 1948. In Temperature: Its Measurement and Control Vol. 3, pp. 547-579. Reinhold, New York.

SYONO Y.. ITO A. and MORIMOTO S. (1981) Systematics of Mössbauer parameters in ${ }^{57} \mathrm{Fe}$-doped titanate and germanate ilmenites. J. Phys. Chem. Solids 42, 483-486.
TAYLOR L. A.. WILliams R, J, and MCCALLister R, H (1972) Stability relations of ilmenite and ulvöspinel in the Fe-Ti-O system and application of these data to lunar mineral assemblages. Earth Plan. Sci. Lett. 16, 282-288.

TAYLOR R. W. and SCHMALZREID H. (1964) Free energy of formation of some titanates, silicates, and $\mathrm{Mg}$-aluminate from measurements made with galvanic cells involving solid electrolytes. J. Phys. Chem. 68, 2444.

UlBRICH H. H. and WALDBaUM D. R. (1976) Structural and other contributions to third-law entropies of silicates. $(\mathrm{rec}$ chim. Cosmochim. Acta 40, 1-24.

VELDE D. (1975) Armalcolite-Ti-phlogopite-diopside-analcite bearing lamprophyres from Smokey Butte. Garfield County. Montana. Amer. Mineral. 60, 566-573.

WebSter A. H. and Bright N. F. H. (1966) The system iron-titanium-oxygen at $1200^{\circ} \mathrm{C}$ and oxygen partial pressures between $1 \mathrm{Atm}$. and $2 \times 10^{-14} \mathrm{Atm}$. J. Amer. (eram Soc 44, 110-116.

Westrum E. F. JR.. Furukawa G. T. and MCOUllough J. T. (1968) Adiabatic low-temperature calorimetry, In E:perimental Thermodynamics (eds. J. T. MCCULLoLGH and D. W. SCOTT). Vol. 1. pp. 133-214. Butterworth's \& CO. Lid. London.

WoOD B. J. (1981) Crystal-field electronic effects on the thermodynamic properties of $\mathrm{Fe}^{2+}$ minerals. In Thermedynamics of Minerals and Mells (eds. R. C. NEWION. A. NAVROTSKY and B. J. WOOD), pp. 63-84. Springer-Verlag.

YU T. H., LIN S. J., ChaO P. FANG C. S. and HUANG C. S. (1974) A preliminary study of some new minerals of the platinum group and another associated new one in platinum-bearing intrusions in China. Acta Geologica Sinica 2. $202-218$. 